\title{
Sensing and processing whisker deflections in rodents
}

\author{
Thomas F Burns ${ }^{\text {Corresp., } 1}$, Ramesh Rajan ${ }^{\text {Corresp. } 1}$ \\ ${ }^{1}$ Biomedicine Discovery Institute, Monash University, Melbourne, Victoria, Australia \\ Corresponding Authors: Thomas F Burns, Ramesh Rajan \\ Email address: t.f.burns@gmail.com, ramesh.rajan@monash.edu
}

The classical view of sensory information mainly flowing into barrel cortex at layer IV, moving up for complex feature processing and lateral interactions in layers II and III, then down to layers $\mathrm{V}$ and $\mathrm{VI}$ for output and corticothalamic feedback is becoming increasingly undermined by new evidence. We review the neurophysiology of sensing and processing whisker deflections, emphasizing the general processing and organisational principles present along the entire sensory pathway - from the site of physical deflection at the whiskers to the encoding of deflections in the barrel cortex. Many of these principles support the classical view. However, we also highlight the growing number of exceptions to these general principles, which complexify the system and which investigators should be mindful of when interpreting their results. We identify gaps in the literature for experimentalists and theorists to investigate, not just to better understand whisker sensation but also to better understand sensory and cortical processing. 


\section{Sensing and processing whisker deflections in}

\section{2 rodents}

3

5

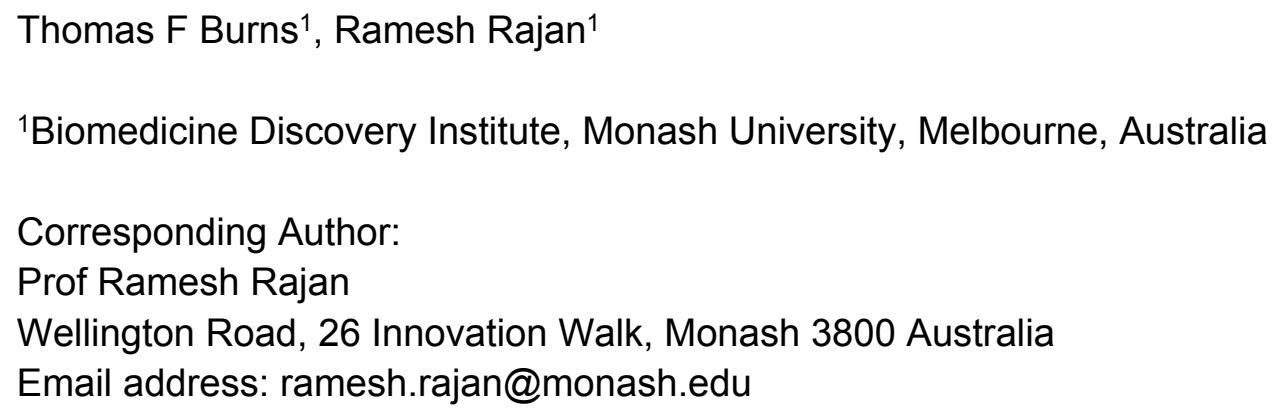

\section{Abstract}

The classical view of sensory information mainly flowing into barrel cortex at layer IV, moving up for complex feature processing and lateral interactions in layers II and III, then down to layers $\mathrm{V}$ and $\mathrm{VI}$ for output and corticothalamic feedback is becoming increasingly undermined by new evidence. We review the neurophysiology of sensing and processing whisker deflections, emphasizing the general processing and organisational principles present along the entire sensory pathway - from the site of physical deflection at the whiskers to the encoding of deflections in the barrel cortex. Many of these principles support the classical view. However, we also highlight the growing number of exceptions to these general principles, which complexify the system and which investigators should be mindful of when interpreting their results. We identify gaps in the literature for experimentalists and theorists to investigate, not just to better understand whisker sensation but also to better understand sensory and cortical processing.

\section{Introduction}

Sensory information is vital for interacting with the world and fulfilling the basic requirements for human survival, socialization, and cooperation. We use combinations of sensory data streams auditory, visual, touch, etc. - to interpret and form internal maps of the outside world. It is therefore often debilitating for humans to experience minor or major sensory deficits or perturbations in sensory processing pathways, and such debilitations come at broader social and economic costs (WHO Programme for the Prevention of Deafness and Hearing Impairment., 2001, 2010). For example, partial or complete hearing loss can generate significant stress on familial bonds, $-$ 
37 general communication, and personal confidence (Lucas, Katiri, \& Kitterick, 2018; Wood Jackson 38 \& Turnbull, 2004). Thus, the study of such sensory systems and their deficits is important for 39 human health and wellbeing. Sensory systems are also ideal for basic neuroscience study 40 because sensory information is processed in dedicated, known and highly-structured neural 41 pathways from periphery to cortex and, for the purposes of experimentation, sensory input can 42 be easily manipulated over scales from reductionist through to complex naturalistic stimuli. This 43 allows detailed study of broad questions about how neurons connect and form networks to carry 44 out computations, as well as how different alterations in health states affect these networks. The 45 current review focusses on barrel cortex, a highly specialized region of rat cortex for sensing and 46 processing whisker deflections. By understanding this system in detail, it may enable us to generate more a more general understanding of sensory systems and processing.

For bioethical and practical reasons, it is not always preferable or possible to study neural tissues from humans. However, ethical guidelines have been developed for the use of non-human animals (Blakemore, Clark, Nevalainen, Oberdorfer, \& Sussman, 2012), and brain development and likeness to human brains in this context has been studied in detail in relevant non-human animals, particularly rodents (Semple, Blomgren, Gimlin, Ferriero, \& Noble-Haeusslein, 2012) which have become popular models for studying brain injury (Carron, Alwis, \& Rajan, 2016) and for basic neuroscience generally (Reid \& Koch, 2012). Given the ecological niche they occupy, the rodent face whiskers act as important sensing organs to probe the environment and to interact with conspecifics, especially in the low-light nocturnal conditions when rodents are most active. The whiskers are readily manipulated and the relevant parts of somatosensory cortex are easily accessed via surgery; hence, study of whisker-sensation in rodents has been ongoing in basic and sensory neuroscience for many years (Feldmeyer, Egger, Lübke, \& Sakmann, 1999; Jensen \& Killackey, 1987; Lavzin, Rapoport, Polsky, Garion, \& Schiller, 2012; Phoka, Wildie, Schultz, \& on neural function and structure (Alwis, Yan, Morganti-Kossmann, \& Rajan, 2012; Carron et al., 2016; Johnstone, Shultz, Yan, O’Brien, \& Rajan, 2014).

\section{Rationale and Survey Methodology}

In this review, we outline the basic state of knowledge of rodent whisker-sensation physiology and identify several opportunities for investigators to expand our understanding through filling gaps in the literature. This literature review is therefore useful for junior and senior researchers interested in sensory neuroscience, particularly whisker sensation in rodents. 
87

To find relevant literature for this review, we used the PubMed and Google Scholar literature search engines. We searched for literature including all combinations of the following keywords in their titles or abstracts: "barrel cortex", "whisker", "sensory processing", "sensory pathway", "thalamocortical pathway", "somatopy", "microcircuit", "inhibition”, "septa”, and "cortical column". Results from these searches were combined between all searches and between PubMed and Google Scholar such that all duplicates were discarded. Only peer-reviewed original research, reviews, and book chapters were included. Results were excluded if the paper/review/book chapter focused on animals which were not mice or rats or focused on aspects of the physiology or biology which was unrelated to whisker sensation.

The main part of our review is structured to match the information flow through the sensory pathways of whisker sensation in rodents, starting from the whisker itself and ending in the barrel cortex. We first outline the general structural elements in the pathways which allow rats to receive information about the world from their whisker movements. Next, we discuss the importance of different neuron subtypes in the microcircuits of the somatosensory cortex, where perception occurs. We then briefly discuss the concept of population coding, especially temporal coding, in the context of barrel cortex.

\section{Whisker-sensing pathways to barrel cortex}

Sensory whiskers, or vibrissae, are composed of a keratin shaft which extends out from a mammal's body. The shaft itself does not contain nerve fibres but its mechanical manipulation activates mechanoreceptors at its base (Dehnhardt, Hyvärinen, Palviainen, \& Klauer, 1999; Ebara, Kumamoto, Matsuura, Mazurkiewicz, \& Rice, 2002; J. N. Kim, Koh, Lee, Park, \& Song, 2011; Marshall, Amin, Kovacs, \& Lydersen, 2006; Melaragna \& Montagna, 1953; F L Rice, Mance, \& Munger, 1986; Stuttgen, Ruter, \& Schwarz., 2006). Despite its lack of nervous tissue, the geometry and mechanical characteristics of the whisker itself has significant follow-on effects ascending the sensory pathway. For example, isolated whiskers have been shown to naturally resonate at frequencies ranging from $30-750 \mathrm{~Hz}$ (where frequency is proportion to whisker length) and passively damp vibrations or deflections (Hartmann, Johnson, Towal, \& Assad, 2003; Neimark, Andermann, Hopfield, \& Moore, 2003). Sinus pressure near the base of the whisker may further aid in the passive, reflexive, or active modulation of the whisker's mechanical responses and thus the overall sensory transduction (Neimark et al., 2003; Frank L. Rice, Mance, \& Munger, 1986), as originally suggested for shrews (Yohro, 1977). The mechanoreceptors which ultimately send this sensory information exist in a wide variety (Melaragna \& Montagna, 1953) 
105

106

107

108

109

110

111

112

113

114

115

116

117

118

119

120

121

122

123

124

125

126

127

128

129

130

131

132

133

134

135

136

137

138

and also exhibit different stimulus feature specificities and firing adaptation rates (Lichtenstein, Carvell, \& Simons, 1990; Zucker \& Welker, 1969).

In the case of the rat, whiskers are innervated by a purely sensory branch of the ventrolateral trigeminal nerve called the infraorbital nerve. First-order bipolar afferent neurons innervate the whisker base and synapse in the sensory trigeminal nuclei (Lazarov, 2002). From here, second-order afferents project to various subcortical nuclei in the brain (Morton, 2013) in complex, detailed arrangements (M. A. Castro-Alamancos, 2015; Manuel a Castro-Alamancos, 2002; Miyata \& Imoto, 2006) (see Figure 1 for a summary of these pathways). The main divisions of these afferent pathways to thalamus are the lemniscal, paralemniscal, and extralemniscal. This leads to independent levels of activation of the ventroposterior medial nucleus (VPM) and the medial posterior nucleus (POm), the two major thalamic nuclei which will relay the information to cortex. VPM receives afferents from the lemniscal pathway (in its doromedial sector) and the extralemniscal pathway (in its ventrolateral sector) (Pierret, Lavallee, \& Deschenes, 2000), whereas POm receives afferents only from the paralemniscal pathway. The connection patterns of second-order afferents to VPM and POm achieve two things. First, the system maintains a highly organised and systematic representation of information sent by the individual whiskers (Land, Buffer, \& Yaskosky, 1995; Pierret, Lavallée, \& Deschênes, 2000; Saporta \& Kruger, 1977).

Second, it establishes VPM and POm as distinct, specialised information streams relaying different types of information to cortex (see Figure 1 for illustration). For example, the lemniscal pathway via VPM may encode spatial information while the paralemniscal pathway via POm encodes temporal information (Ahlssar, Sosnik, \& Haldarilu, 2000; Yu, Derdikman, Haidarliu, \& Ahissar, 2006). The extralemniscal pathway via VPM may represent a combination of spatial and temporal information (Yu et al., 2006), which may or may not make VPM a more general mixture of information, except to say that specific divisions within VPM seem well-defined and differentially innervate the cortex (Pierret, Lavallee, et al., 2000). The VPM and POm pathways also show differences in corticothalamic interactions, modulating their own responses to activity in cortex (Diamond, Armstrong-James, \& Ebner, 1992) and superior colliculus (Gharaei, Honnuraiah, Arabzadeh, \& Stuart, 2020).

The reticular nucleus of the thalamus (NRT) is a common source of inhibition to both VPM and POm. It is activated by corticothalamic feedback and can provide lateral inhibition to neighbouring segments of thalamus representing other, nearby whiskers to inhibit the primary whisker represented by another given segment of thalamus (Fernandez et al., 2017; Landisman et al., 2002; Lavallée \& Deschênes, 2004; Sohal \& Huguenard, 2003; Varga, Sík, Lavallée, \& Deschênes, 2002). VPM primarily receives inhibition via NRT whereas POm receives additional, 
139 intra- and extra-thalamic inhibition (Bokor et al., 2005). These additional sources of inhibition 140 normally silence POm activity during regular whisker activation (Barthó, Freund, \& Acsády, 2002;

141 Lavallée et al., 2005; Trageser \& Keller, 2004). The activity of VPM and POm are also susceptible

142 to corticothalamic feedback, especially from cortical layers V and VI (Bourassa, Pinault, \& 143 Deschenes, 1995; M. A. Castro-Alamancos, 2004; M a Castro-Alamancos \& Calcagnotto, 1999; 144 Deschênes, Veinante, \& Zhang, 1998; Golshani, Liu, \& Jones, 2001; McCormick \& von Krosigk, 145 1992; Sherman \& Guillery, 1998)(Golshani et al., 2001). Corticothalamic fibres sent to POm are 146 thought to the main drivers of POm, and fibres sent to VPM help modulate incoming activity. 147 Corticothalamic fibres originating from cortical layer VI have especially strong synapses 148 (Hoogland, Wouterlood, Welker, \& Van der Loos, 1991) and are similar in strength to second149 order afferent synapses (Reichova, 2004) (while most other corticothalamic synapses are 150 relatively weak). In addition to these cortical feedback mechanisms, VPM is additionally 151 modulated by the brainstem (M. A. Castro-Alamancos, 2015). In combination, these sources of 152 inhibition, feedback, and modulation (see Figure 1 for diagrammatic summary) therefore shape 153 the responses of intrinsically excitable thalamocortical cells (Manuel a Castro-Alamancos, 2002; 154 Steriade, Jones, \& McCormick, 1997) in VPM and POm, which receive sensory information from 155 second-order afferents. In summary, this means the cortex receives a signal which is processed 156 by sub-cortical structures and also distributed by those structures to arrive in specific parts of 157 cortex.

158

159

Barrel cortex somatotopy and microcircuitry

160

161

In rodents, whisker sensation is represented in the posteromedial barrel subfield (PMBSF) region 162 of somatosensory cortex, commonly known as barrel cortex due to specializations in the 163 organization of neurons in the input layer IV as described below. The PMBSF occupies 164 approximately $70 \%$ of primary somatosensory cortex and $13 \%$ of the cortical surface (L.-J. Lee \& 165 Erzurumlu, 2005), a disproportionately large part of cortex relative to the small external physical size of the whiskers when compared to other parts of the rodent body. This indicates the ecological importance of whisker somatosensation in comparison to other tactile inputs. The PMBSF is organised somatopically, meaning each of the major facial whiskers is represented, whisker for whisker, in separate columns of neurons extending from the surface to the white matter. Each of these regions, which receives a dominant principal whisker (PW) input, is defined anatomically by the organization of layer IV neurons into 'barrel' like structures with a relatively hollow interior. They are laid out in a grid formation in the PMBSF. The cortical layers above and 
173 below a layer IV barrel are often referred to as a 'barrel column' and together represent the cortical 174 column responsible for processing the sensory input from one whisker. The grid formation in 175 PMBSF consists of arcs (columns) and rows of whisker barrels, each representing the same arcs 176 and rows of whiskers found in the whisker pad on the rat face (and this organisation is maintained 177 through the brainstem, thalamus, and cortex). 'A1' represents the top-most whisker at the nose 178 bridge end, 'A2' the whisker one closer to the nose in the same row, and so on, right through to 179 'E8', which represents the bottom-most whisker at the nose end (n.b. some species-, individual-, 180 and reporting-specific differences will mean a slightly different end whisker count).

181 Classically, each whisker barrel receives its primary thalamic input mainly at layer IV. This 182 sensory information is then projected up to layers II and III for further processing (along with other 183 local cortical areas), then down to layers $\mathrm{V}$ and $\mathrm{VI}$ for final output to more distant cortical areas, 184 such as motor cortex (as well as sending feedback to sub-cortical areas) (Radnikow et al., 2015). 185 Layer IV excitatory cells typically have strong, narrow tuning to single whiskers while cells in 186 supra- and infra-granular layers typically show broader, mixed-strength tuning (indicating tuning 187 to more precise, higher-order features, and possibly common to multiple whiskers, as indicated 188 by generally narrower receptive fields in layer IV compared to other layers (Brecht, Roth, \& 189 Sakmann, 2003; Brecht \& Sakmann, 2002a) and more complex sensory information generally 190 being computed and integrated in cortex in layers other than layer IV (Bale \& Maravall, 2018; 191 Lyall, Mossing, Pluta, Dudai, \& Adesnik, 2020; O'Herron, Levy, Woodward, \& Kara, 2020)). 192 Neurons across all layers, but particularly infragranular layers, can be tuned to temporal or 193 qualitative features of whisker deflection, e.g. directional sensitivity or initial versus sustained 194 parts of deflection. Such differences are the result of interaction between the increasing number 195 of complex microcircuits being identified (Feldmeyer, 2012; Narayanan et al., 2015; Vitali and 196 Jabaudon, 2014) both within and between layers, and within and between barrels (Bosman et al., 197 2011). For instance, the septa are innervated by a separate thalamic pathway to the barrels (see 198 Figure 1), and their lateral connections between barrels (Narayanan et al., 2015) likely modulate 199 individual barrels' activity. Where (Feldmeyer, 2012) and how (Hanno S. Meyer et al., 2010) 200 thalamocortical cells connect within the cortical layers is another source of these differences. And 201 while the VPM and POm pathways appear to target cortex in complementary ways, the relevant 202 feedforward (Cruikshank et al., 2010; Lavallée et al., 2005; N. Suzuki and Bekkers, 2012) and 203 feedback (Feldmeyer, 2012; J. Kim et al., 2014) systems within cortex make the subsequent 204 interlaminar interactions all the more complex, thus interesting and important for sensory 205 processing. For these reasons, the classical, simple view of information flowing neatly and wholly 206 from layer IV, up to II/III, then down to V is increasingly being reinforced in general principle while 
207 also undermined by long lists of special cases. In the following sub-sections, we will attempt to 208 follow the general principle view in detail, layer-by-layer, and discuss the implications of relevant 209 special cases.

210

211

\section{Layer IV}

Layer IV is the primary input layer from the thalamus and typically has narrow, strong tuning to a single PW. It helps to amplify and further filter the thalamic signal and distribute its activity to other cortical layers, primarily the supragranular layers (Cowan \& Stricker, 2004; Feldmeyer, 2012; Staiger et al., 2004).

In the classical pathway, VPM afferents first synapse onto both excitatory and inhibitory cells in layer IV (E. L. White \& Rock, 1979), with more synapses onto excitatory than inhibitory cells as the ratio of excitatory to inhibitory cells in layer IV is approximately 9:1 (Lefort, Tomm, Floyd Sarria, \& Petersen, 2009). That said, the vast majority (approximately 85\%) of synaptic contacts in layer IV are intracortical (E. L. White \& Rock, 1979), i.e. from other areas of (mostly barrel) cortex. Thalamocortical synapses are only slightly more efficacious than intracortical synapses, with evidence that the relative strength of thalamocortical synapses is due to coincident activation of a number of such inputs rather than significantly stronger synapses (Jia, Varga, Sakmann, \& Konnerth, 2014). Although, their synapses are also slightly more proximal to somas of layer IV spiny stellate, excitatory cells than are intracortical synapses, which may contribute to the fast lateral inhibition suggested by physiological and functional studies on roughness discrimination (Hartings \& Simons, 1998; Pinto, Brumberg, \& Simons, 2000; Shoykhet, Doherty, \& Simons, 2000; Temereanca \& Simons, 2003).

The excitatory cells in layer IV are predominantly spiny stellates, star pyramids, and nonstar pyramids (Brecht \& Sakmann, 2002b; Bruno \& Sakmann, 2006; Jones, 1975; Lübke, Egger, Sakmann, \& Feldmeyer, 2000; Dirk Schubert, Kotter, Zilles, Luhmann, \& Staiger, 2003; Staiger, Bojak, Miceli, \& Schubert, 2014), all innervated by VPM afferents. There are some morphological and functional differences between them (Egger, Nevian, \& Bruno, 2008; Staiger et al., 2004), but they mostly differ in connectivity to other layers and columns (Cowan \& Stricker, 2004; Egger et exclusively within layer IV and to layer II and III, and very rarely to infragranular layers; star pyramids have dendrites which extend from layer IV into II and III and axons which project to layer 
240 layer IV mainly target layers II and III in the same column (with an overall connectivity probability 241 of $\sim 10-15 \%$ with layer II/III pyramidal cells; (Feldmeyer, Lübke, Silver, \& Sakmann, 2002; Lefort 242 et al., 2009)). Within layer IV, excitatory cells appear to form excitatory clusters of $\leq \sim 10$ cells in 243 which the cells are highly interconnected (Lefort et al., 2009), making individual cells in these 244 clusters highly efficacious in causing action potentials in other cells of the same cluster 245 (Feldmeyer et al., 1999).

Excitatory cell activity in all cortical layers is modulated by interneuron cells located locally

247 (from within the same layer of the same column), translaminarly (from other layers within the same 248 column), and laterally (from layers within other columns). These interneurons come in different 249 and complex morphological and electrical varieties, are present and connected in different 250 proportions and manners throughout cortex, and can have inhibitory or excitatory synapses with other cells (though most are inhibitory) (DeFelipe et al., 2013; Halabisky, 2006; Markram et al., 2004). This diversity can make precise identification of interneuron subtypes difficult under experimental conditions, and in many reports of microcircuits, only some features of the interneurons are known. However, a common technique to identify them takes advantage of their differential expressions of calcium-binding proteins (CBPs), neuropeptides, and other molecular markers (Druckmann, Hill, Schürmann, Markram, \& Segev, 2013; Kubota, Karube, Nomura, \& Kawaguchi, 2016; Markram et al., 2004) (see Table 1). In the case of layer IV interneurons, VPM afferents activate cells positive for parvalbumin $\left(\mathrm{PV}^{+}\right)$, somatostatin $\left(\mathrm{SOM}^{+}\right)$, and $5-\mathrm{HT}_{3 \mathrm{~A}}$ receptors 259 $\left(5-\mathrm{HT}_{3 \mathrm{~A}} \mathrm{R}^{+}\right.$) (Beierlein, Gibson, \& Connors, 2003; S. Lee, Hjerling-Leffler, Zagha, Fishell, \& Rudy, 2010; Porter, Johnson, \& Agmon, 2001). $\mathrm{PV}^{+}$interneurons are also driven by layer IV excitatory cells (Bosman et al., 2011; Koelbl, Helmstaedter, L'bke, \& Feldmeyer, 2015) and layer VI corticothalamic pyramidal cells (J. Kim, Matney, Blankenship, Hestrin, \& Brown, 2014). Together, these excitatory connections onto inhibitory cells can be considered feedforward inhibition, as they drive inhibitory interneurons' activity forward onto other cells. Feedback inhibition occurs when inhibitory cells synapse back onto excitatory cells, typically releasing gamma-aminobutyric acid (GABA). $\mathrm{PV}^{+}, \mathrm{SOM}^{+}$, and $5-\mathrm{HT}_{3 \mathrm{~A}} \mathrm{R}^{+}$layer IV interneurons cause feedback inhibition on layer IV excitatory cells (Chittajallu, Pelkey, \& McBain, 2013; Koelbl et al., 2015; H. Xu, Jeong, Tremblay, \& Rudy, 2013) and $\mathrm{SOM}^{+}$interneurons cause disinhibition (inhibiting other inhibitory 269 cells, thus reducing their inhibition onto excitatory cells) on $\mathrm{PV}^{+}$interneurons (H. Xu et al., 2013). Functionally, $\mathrm{PV}^{+}$interneurons appear to be mostly fast-spiking (FS) and can produce very high, non-adapting firing rates $(>100 \mathrm{~Hz})$. They synapse almost exclusively onto excitatory cells 272 in layer IV and are likely to be basket cells (BCs; see Table 1) which typically possess a dense axonal plexus that projects within a small area (Koelbl et al., 2015; Porter et al., 2001). These 
$274 \mathrm{PV}^{+}-\mathrm{FS}$ cells have very short latencies to cortical activation $(0.6 \mathrm{~ms})$, high release probabilities, 275 and make an average of 3.5 synapses onto excitatory cell dendrites at proximal and distal 276 locations (Koelbl et al., 2015). It has therefore been suggested (Radnikow, Qi, \& Feldmeyer, 2015) 277 that as these $\mathrm{PV}^{+}-\mathrm{FS}$ cells are rapidly recruited by thalamocortical afferents and further driven by 278 local excitatory cells, they may act to quickly 'reset' layer IV excitation and increase temporal 279 resolution in that layer. Relatively FS $(70-150 \mathrm{~Hz})$, adaptive firing from $\mathrm{SOM}^{+}$cells likely provides 280 the required disinhibitry control of $\mathrm{PV}^{+}-\mathrm{FS}$ cells (Ma, Hu, Berrebi, Mathers, \& Agmon, 2006); 281 synapses from $\mathrm{SOM}^{+}$to $\mathrm{PV}^{+}$- FS cells are much stronger than those from $\mathrm{SOM}^{+}$to excitatory cells 282 within layer IV (H. Xu et al., 2013). However, a different subtype of SOM ${ }^{+}$interneuron in layer IV 283 are likely to be the Martinotti cells which are identifiable by axons projecting to layer I (Ma et al., 284 2006) and provide widespread cortical dampening to pyramidal neurons (Silberberg \& Markram, 285 2007) (Table 1). Then, 5- $\mathrm{HT}_{3 \mathrm{~A}} \mathrm{R}^{+}$interneurons - which appear in comparatively low numbers in 286 this layer - show long firing latencies and result in slow inhibition on excitatory cells within layer 287 IV (Chittajallu et al., 2013; S. Lee et al., 2010; Rudy, Fishell, Lee, \& Hjerling-Leffler, 2011), acting 288 weakly but surely against $\mathrm{PV}^{+}-\mathrm{FS}$ cells' temporal sharpening. This could counteract excitation289 inhibition imbalances or provide the wider temporal integration necessary for long-term 290 neuroplasticity (Radnikow et al., 2015).

291

292

\section{Layer II and III}

293 The main layer IV excitatory output is to layers II and III, where it combines with additional VPM 294 input to layer III pyramidal cells (Arnold, Li, \& Waters, 2001; Jensen \& Killackey, 1987; Hanno S. 295 Meyer et al., 2010; Marcel Oberlaender et al., 2012) and POm input to apical tufts of layer II 296 pyramidal cells (Ohno et al., 2012; Radnikow et al., 2015). Together, layers II and III act as the 297 first and major integrative processing cortical layers. Pyramidal cells in layer II and III typically 298 project their axons over several barrel columns in layers II, III, and V, and to secondary 299 somatosensory and motor cortices (Aronoff et al., 2010; Feldmeyer, Lübke, \& Sakmann, 2006). 300 However, layer II pyramidal cells near the border of layers I and II have highly lateralized apical 301 dendrites, and a small subset of layer III pyramidal cells restrict their projections to mostly within 302 one barrel (Bruno, Hahn, Wallace, de Kock, \& Sakmann, 2009; DeLaine D. Larsen \& Callaway, 303 2006). Within layer II and III, pyramidal neurons form excitatory connections to one another with 304 a probability of $\sim 10-20 \%$, as layer IV excitatory cells connect to layer II and III pyramidal cells 305 (Feldmeyer et al., 2006; Holmgren, Harkany, \& Zilberter, 2003). These intralayer connections 306 between layer II and III pyramidal cells are typically on the order of $\sim 3$ synaptic connections per 
307 neuron (to mostly basal dendrites) (Feldmeyer et al., 2006; Sarid, Feldmeyer, Gidon, Sakmann, 308 \& Segev, 2015), however the strength of these connections depends on sensory experience 309 (Cheetham, Hammond, Edwards, \& Finnerty, 2007). Axons from layer II and III pyramidal neurons 310 also project to layer $\mathrm{V}$ pyramidal neurons, typically forming weak synapses on basal dendrites 311 (Petreanu, Mao, Sternson, \& Svoboda, 2009; Reyes \& Sakmann, 1999; D. Schubert, Kötter, 312 Luhmann, \& Staiger, 2006), and these connection patterns may 'bind' perceptual features in 313 subnetworks of layer $\mathrm{V}$ pyramidal cells through learning rules such as spike timing-dependent 314 synaptic plasticity (Kampa, Letzkus, \& Stuart, 2006) and to generate combinations of such 315 features for output to other cortical areas (see section 'Layer V'). .

As in layer IV, the output of layer II and III pyramidal neurons is shaped by many interneurons, particularly in layer II where $\sim 17 \%$ of cells are interneurons, whereas interneurons make up only $\sim 9 \%$ in layer III and $\sim 8-9 \%$ in layer IV (H. S. Meyer et al., 2011). All major histological classes of interneurons are represented in layers II and III (Gentet, 2012) but approximately half are $5-\mathrm{HT}_{3 A} \mathrm{R}^{+}$, meaning they can be driven by serotonergic neurons (Rudy et al., 2011). Layer II and III interneurons are mainly driven by layer IV excitatory cells (Helmstaedter, Staiger, Sakmann, \& Feldmeyer, 2008), causing feedforward inhibition, but layer II and III pyramidal neurons also activate feedforward inhibition circuits by synapsing with some FS (possible BC) layer II and III interneurons (Avermann, Tomm, Mateo, Gerstner, \& Petersen, 2012; Holmgren et al., 2003). A wide variety of interneurons, each with unique intrinsic properties and functions, are likely to exist in layer II and III, including BCs, Martinotti cells (MCs), chandelier cells (ChCs), neurogliaform cells (NGFCs), double bouquet cells (DBCs), bitufted cells (BTCs), and bipolar cells (BPCs) (DeFelipe et al., 2013; Jiang, Wang, Lee, Stornetta, \& Zhu, 2013; A. J. Lee et al., 2014; Markram et al., 2004) (see Table 1 for basic descriptions of these cells and their identifying characteristics). ChCs target axon initial segments of layer II and III pyramidal neurons (where they can be uniquely excitatory (Szabadics et al., 2006)), while BCs, DBCs, and some NGFCs synapse onto basal dendrites of local pyramidal neurons; BPCs target proximal apical dendrites; and MCs and BTCs synapse on apical tufts and the middle portion of the apical dendrites. On average, most of these interneurons will synapse onto three to six pyramidal neurons in layer II and III and make similar kinds and numbers of connections with layer $\mathrm{V}$ pyramidal neurons. These interneuronal connections onto layer II and III pyramidal cells, in combination with the intricate excitatory connection patterns from layer IV and thalamus, allows cells to be finely tuned to complex, higher-order features of sensory input (Bale \& Maravall, 2018; Lyall et al., 2020; O'Herron et al., 2020). 
340

341

342

343

344

345

346

347

348

349

350

351

352

353

354

355

356

357

358

359

360

361

362

363

364

365

366

367

368

369

370

371

372

In addition to these local interactions, there are also some interesting $\mathrm{BC}$-involving microcircuits in which BCs are innervated by long-range vibrassal motor cortex (VM1) axons which synapse onto BCs' apical dendrite extensions in layer I of barrel cortex. These BCs cause a strong disinhibition of $\mathrm{SOM}^{+}$interneurons in layer II and III, and thus activity from vM1 projections can increase the excitability of layer II, III, and V pyramidal neurons, as seen during whisking behaviour in vivo (Lee, Kruglikov, Huang, Fishell, \& Rudy, 2013; H. Xu et al., 2013). Layer IV excitatory neurons in secondary somatosensory cortex have also been shown to drive an important long-range feedback pathway to barrel cortex, affecting orientation tuning within barrel cortex (Minamisawa, Kwon, Chevée, Brown, \& O’Connor, 2018).

Highly peculiar layer II and III inhibitory microcircuits involving $\mathrm{PV}^{+}$and calretinin-positive $\left(\mathrm{CR}^{+}\right)$interneurons have also been observed (Blatow et al., 2003; Caputi, Rozov, Blatow, \& Monyer, 2009). These $\mathrm{PV}^{+}$cells are called multipolar bursting cells (MPBCs) as they show burst rather than FS firing when depolarised and project densely within layer II, with some collaterals to layer V. The $\mathrm{CR}^{+}$cells are BPCs and multipolar cells (MPCs) - BPCs project narrowly down to layer $V$ and, like MPBCs, have a high-frequency burst upon initial depolarisation, whereas MPCs' axons project laterally within layer II and III only. These peculiar circuits are driven and modulated by layer II and III pyramidal cells, with MPBCs receiving extra inputs from layer IV excitatory cells.

\section{Layer $\mathrm{V}$}

Layer $\mathrm{V}$ receives excitation and inhibition from all overlying layers and, combined with excitatory input from VPM and POm, likely integrates the processing of the column as a whole before sending its processed output to downstream areas. The substantial thalamic input, particularly from VPM (Constantinople \& Bruno, 2013), also challenges the conventional view of sensory information mainly arriving in cortex at layer IV. Layer $\mathrm{V}$ pyramidal neurons receive innervation from supragranular and granular excitatory cells, as well as other layer $\vee$ pyramidal neurons. Of these supragranular and granular cells, three morphologies are distinguishable: slender-tufted (found mostly in upper layer $\mathrm{V}$ ), thick-tufted (found mostly in lower layer $\mathrm{V}$ ), and untufted (found throughout layer $V$, though in relatively low numbers) (Feldmeyer et al., 2006; DeLaine D. Larsen \& Callaway, 2006). Slender-tufted pyramidal neurons receive thalamic input from POm and project dense axons extensively within supragranular layers across the entire ipsilateral barrel cortex, ipsilateral VM1, and to contralateral barrel cortex, making them the primary output cells in layer V (Delaine D Larsen, Wickersham, \& Callaway, 2007; M. Oberlaender et al., 2011). Thicktufted pyramidal neurons receive thalamic input mostly from VPM and make most of their 
373 synapses to other layer $\mathrm{V}$ pyramidal neurons and subcortical areas, thus providing local and 374 subcortical feedback (Delaine D Larsen et al., 2007; Veinante, Lavallée, \& Deschênes, 2000). 375 Untufted pyramidal neurons receive a mix of VPM and POm thalamic input depending on their 376 depth within layer $\mathrm{V}$ and project extensively to layer III and to the contralateral barrel cortex, 377 making them important for intracolumnar feedback and inter-hemispheric coordination of sensory 378 outputs (DeLaine D. Larsen \& Callaway, 2006; Le Bé, Silberberg, Wang, \& Markram, 2007).

As in other layers of cortex, the activity of pyramidal neurons in layer $V$ receives inhibitory modulation - from other layers, especially layer II and III interneurons as discussed above, as

381

382

383

384

385

386

387

388

389

390

391

392

393

394

395

396

397

398

399

400

401

402

403

404

405

well as local layer $\mathrm{V}$ inhibition. Local Inhibition comes from $\mathrm{PV}^{+}, \mathrm{FS}$ and $\mathrm{SOM}^{+}$cells driven by VPM (Tan, Hu, Huang, \& Agmon, 2008), FS cells driven by upper layer VI pyramidal cells (J. Kim et al., 2014), and local MCs (Berger, Silberberg, Perin, \& Markram, 2010; Silberberg \& Markram, 2007). Local $\mathrm{PV}^{+}, \mathrm{FS}$ and MCs generally behave as in other cortical layers but $\mathrm{SOM}^{+}$cells synapse onto dendrites of layer IV spiny stellate cells instead of apical dendrites of local pyramidal cells as in other layers (Tan et al., 2008). Because of this, their delayed facilitation response effectively adds a late-onset inhibitory input to layer IV excitation during long periods of ongoing thalamocortical input and so could be important for excitation-inhibition balance at longer-time scales.

\section{Layer I}

Layer I, also known as the molecular layer, contains few neuron cell bodies and many glia. It receives input from thalamic matrix cells and acts as a medium through which feedback and transmission from ipsilateral and contralateral cortical areas can communicate (Jiang et al., 2013; A. J. Lee et al., 2014; Rubio-Garrido, Pérez-De-Manzo, Porrero, Galazo, \& Clascá, 2009; Wozny \& Williams, 2011). Except for Cajal-Retzius cells, which are important during neurodevelopment (Hevner, Neogi, Englund, Daza, \& Fink, 2003; Imamoto, Karasawa, Isomura, \& Nagatsu, 1994), the mature layer I almost exclusively contains GABAergic inhibitory neurons expressing $5-\mathrm{HT}_{3 \mathrm{~A}} \mathrm{R}^{+}$ and $\mathrm{SOM}^{+}$(Rudy et al., 2011; N. Xu et al., 2012), which are predominately driven by layer II/III pyramidal cells from the same column (Wozny \& Williams, 2011). These layer I interneurons have some functional spiking differences (Wozny \& Williams, 2011) and have recently been described as possessing two distinct morphologies, each being involved in two distinct microcircuits (Jiang et al., 2013; Larkum, 2013; A. J. Lee et al., 2014): (1) single bouquet cells (SBoCs) establish local, unidirectional inhibition to layer I interneurons and most inhibitory and pyramidal cells in layer II and III; and (2) elongated neurogliaform cells (ENGFCs) establish broad, reciprocal inhibition 
406 (directly and via gap junctions) to layer II and III MCs, NGFCs, and BTCs, as well direct inhibition

407 to layer II, III, and V pyramidal neurons. Therefore, SBoCs exert an indirect, disinhibitory effect 408 on layer $V$ pyramidal cells whereas ENGFCs exert direct and indirect inhibition on layer $V$ 409 pyramidal cells (thus stipulated as a yin and yang system of inhibitory control for layer $\vee$ (Larkum, 410 2013)).

411

412

\section{Layer VI}

413 Relative to other cortical layers, much less is known about layer VI (Thomson, 2010). Its 414 involvement in thalamocortical feedback is well-established (Lam \& Sherman, 2010; Mercer et 415 al., 2005; Perrenoud, Rossier, Geoffroy, Vitalis, \& Gallopin, 2013; West, Mercer, Kirchhecker, 416 Morris, \& Thomson, 2006) but it also makes some unique and varied projections to other layers 417 and acts as a supplementary output layer (Kumar \& Ohana, 2008; Lefort et al., 2009; Mercer et 418 al., 2005; Pichon, Nikonenko, Kraftsik, \& Welker, 2012; Zhang \& Deschênes, 1997). In upper 419 layer VI, pyramidal cells receive input from VPM and POm, and typically project either back into 420 the thalamus, providing corticothalamic feedback, or project intracortically. Intracortical 421 projections are made to other layers of the same cortical column, within layer VI itself, or to long422 range cortical areas outside of barrel cortex. Pyramidal cells in lower layer VI are much more 423 heterogeneous and typically synapse within layer VI, however longer-range connections to layer 424 I, layer II, and the thalamus are also present (Clancy \& Cauller, 1999; Killackey \& Sherman, 2003; 425 Marx \& Feldmeyer, 2013). Interneurons in layer VI are significantly understudied, but are likely 426 driven by thalamic nuclei and local pyramidal cells and appear to be involved in local and 427 translaminar inhibition (Bortone, Olsen, \& Scanziani, 2014; Cruikshank, Urabe, Nurmikko, \& 428 Connors, 2010; Perrenoud et al., 2013; West et al., 2006). Functionally, this makes layer VI highly 429 important for thalamic-cortex interaction, supplementary corticocortical output, and specialised 430 inhibition within a barrel.

431

432

433

Throughout this discussion of barrel cortex microcircuits, some dendritic processing effects have been implied via mention of where presynaptic neurons synapse on postsynaptic 434 cells (soma, perisoma, basal or distal dendrites, etc.). It is important to explicitly note that 435 dendroarchitecture plays an important role in synapse (and, thus, postsynaptic cell) function 436 (Araya, 2014; Bar-llan, Gidon, \& Segev, 2013; Jia et al., 2014; Kurotani, Yamada, Yoshimura, 437 Crair, \& Komatsu, 2008; Lavzin et al., 2012; Schoonover et al., 2014; Stuart, 2012; Varga et al., 438 2002). For example, $\mathrm{GABA}_{\mathrm{B}}$ receptors work by different biochemical mechanisms in the soma 
439 than in dendrites; mostly this means that they have the same resulting effect on postsynaptic firing 440 (Breton \& Stuart, 2012) however exceptions can and do arise due to these differences (Stuart, 441 2012). Complete exploration of such exceptions is beyond the scope of this review but 442 underscores a caveat of dual intracellular somatic recordings (a technique which some studies 443 discussed so far have used): if one is attempting to establish connection probability from 444 presynaptic neurons to a postsynaptic cell, distal dendritic synapses may be so attenuated or 445 filtered that they fail to register at the soma (where the experimenter is often recording from in 446 such studies). However, despite their distal locations, there may be strategies such presynaptic 447 neurons use to boost their signal in vivo (such as synchronous firing with other presynaptic 448 neurons). Thus, in the absence of observing such strategies, studies may significantly 449 underestimate the probability of these presynaptic connections (Radnikow et al., 2015).

In this section on barrel cortex we have also made reference to multiple inhibitory neurons sub-types and their functions (also summarised in Table 1). As a general synthesis of their numerous and complex interactions, both with excitatory neurons and other inhibitory neurons, we notice three general trends: (1) in layers where there are more inhibitory neurons, there is generally more sophisticated or higher level sensory features encoded (layer IV has very few inhibitory neurons compared to layers II and III, for example (Lefort et al., 2009)); (2) inhibitory neurons can act as powerful network control mechanism (we can perhaps see this most clearly in the yin and yang dichotomy of layer l's inhibitory function (Larkum, 2013), but this also evident in long-range connections from other cortical areas (Lee et al., 2013)); and (3) healthy barrel cortex maintains its overall excitatory-inhibitory balance in spite of the diversity of inhibitory neurons in type, number, and proportion in comparison to excitatory cells across different layers, likely due to layer-specific circuitry and connection probabilities (with supports evidence from brain injury models, showing layer-specific inhibitory and excitatory-inhibitory balance effects (Johnstone, Yan, Alwis, \& Rajan, 2013)).

Nevertheless, much is known about barrel cortex and its microcircuits. The sum of

interactions between cortical microcircuits across and within layers ultimately leads to 466 corticocortical output (Aronoff et al., 2010), which transmits essential sensory information upstream to higher sensory, motor, and associative cortical areas.

468

\section{Encoding of whisker deflections}

470

471 What we have discussed - whisker-sensing pathways to barrel cortex, and the barrel cortex's 472 somatotopy and microcircuitry - ultimately serves to generate the neural encoding of whisker 
473 movements in the brain. Such encoding relies not on individual neurons alone, but rather on 474 populations on neurons spread across the cortical column. While populations within the same 475 barrel tend to do have redundancy (Panzeri, Petroni, Petersen, \& Diamond, 2003; Petersen, 476 Panzeri, \& Diamond, 2001), there exist different populations within each barrel, each of which 477 encode complementary features of whisker movements in concert with one another to represent 478 a wide diversity and complexity sensory information (Adibi, McDonald, Clifford, \& Arabzadeh, 479 2014; Campagner, Evans, Loft, \& Petersen, 2018). For example, different populations can encode 480 whisker deflection velocity, amplitude, or angle of deflection. Such populations can also place 481 different emphases on certain quantitative metrics of their coding system, e.g. neurons encoding 482 stimulus location appear to place an emphasis on the timing of individual spikes, especially of the 483 first spike after stimulus onset (Petersen et al., 2001).

Within populations, nearby neurons can fire in pairs during both spontaneous and evoked activity (Maravall, Petersen, Fairhall, Arabzadeh, \& Diamond, 2007). This redundancy allows sampling pairs across the population to provide greater accuracy for determining stimulus onset times (Maravall et al., 2007), which as mentioned is a vital and sensitive metric for encoding stimulus location (Petersen et al., 2001) and many other complex stimulus features of whisker movement (Adibi et al., 2014; Campagner et al., 2018). However, such representations can and do change over time due to adaptation and sensory experience (Adibi et al., 2014; Maravall et al., 2007). These encoding mechanisms are important for the healthy function not only of barrel cortex but may also be important for upstream areas which barrel cortex projects to, such as those responsible for functions such as cognition and motor coordination (Alwis et al., 2012; Carron et transmits information from specific sub-populations of cells within barrel cortex to upstream areas (Chen, Carta, Soldado-Magraner, Schneider, \& Helmchen, 2013) and help to generate coordination between these higher areas in goal-directed motor tasks (Chen, Voigt, Javadzadeh, Krueppel, \& Helmchen, 2016).

\section{Conclusions}

501

502 In this review we have discussed the general principle of sensory information being first received at the whisker, then being transmitted and modified via sub-cortical pathways. This information then flows into layer IV of barrel cortex, up to layers II and III for processing and integration, then down to layers $\mathrm{V}$ and $\mathrm{VI}$ for final processing before output to other areas. Although we emphasized these general processing and organizational principles, we also highlighted many exceptions 
507 which complexify the system, e.g. all cortical layers receive some level of input from the thalamus, 508 although in very different quantities and from distinct thalamocortical pathways, or that some 509 neurons within layers II and III form highly connected intra-cortical circuits instead of connecting 510 laterally to neighbouring barrel columns.

511 Such expectations provide many opportunities to fill gaps in our knowledge of the whisker512 sensing system, for example: What are the characteristics of thalamic innervation of the septa? 513 How does such innervation influence activity in adjacent barrels or vice-versa? For example, do 514 lateral interneuronal circuits in layers II and III form functional microcircuits within the septa? Do 515 such circuits properly 'belong' to any one barrel? Do thalamocortical feedback circuits in layer VI 516 - especially those involving interneurons - interact with these supragranular circuits? What 517 functional differences arise in cortex due to modification of VPM or POm input? How are the VPM 518 or POm pathways modulated by thalamocortical interaction and lateral thalamic interactions via 519 NRT? What are the short- and long-term functional implications of feedback arriving to barrel 520 cortex via layer I or indirect modulation of thalamic input (from BFR, APT, or ZI)? For example, 521 do VM1 projections to barrel cortex (which increase excitability of pyramidal neurons in layers II, 522 III, and V) participate in sensory learning or expectation behaviours? Could short-term adaptation 523 in such circuits further explain certain whisking behaviours or strategies?

524 We believe these and many other questions are worthy of investigation, and that their 525 answers will be relevant to our understanding of other sensory systems and brain processing generally. Many of these questions likely call for close collaboration between experimentalists from different technical backgrounds (electrophysiology, functional imaging, behaviour, immunohistochemistry, anatomy, etc.), as well as computational scientists, engineers, and theorists. Pursuing an even more detailed understanding of how whisker sensation in rodents works is therefore not just good for our scientific understanding, but also for promoting and fostering scientific collaboration across different disciplines.

\section{References}

535

536

537

538

539

540

541

542

543

Adibi, M., McDonald, J. S., Clifford, C. W. G., \& Arabzadeh, E. (2014). Population Decoding in Rat Barrel Cortex: Optimizing the Linear Readout of Correlated Population Responses. PLoS Computational Biology, 10(1). https://doi.org/10.1371/journal.pcbi.1003415

Ahlssar, E., Sosnik, R., \& Haldarilu, S. (2000). Transformation from temporal to rate coding in a somatosensory thalamocortical pathway. Nature, 406(6793), 302-306. https://doi.org/10.1038/35018568

Alwis, D. S., Yan, E. B., Morganti-Kossmann, M.-C., \& Rajan, R. (2012). Sensory Cortex Underpinnings of Traumatic Brain Injury Deficits. PLoS ONE, 7(12). https://doi.org/10.1371/journal.pone.0052169 
544

545

546

547

548

549

550

551

552

553

554

555

556

557

558

559

560

561

562

563

564

565

566

567

568

569

570

571

572

573

574

575

576

577

578

579

580

581

582

583

584

585

586

587

588

589

590

591

592

593

594
Araya, R. (2014). Input transformation by dendritic spines of pyramidal neurons. Frontiers in Neuroanatomy, 8(December), 141. https://doi.org/10.3389/fnana.2014.00141

Arnold, P. B., Li, C. X., \& Waters, R. S. (2001). Thalamocortical arbors extend beyond single cortical barrels: an in vivo intracellular tracing study in rat. Experimental Brain Research, 136(2), 152-168. https://doi.org/10.1007/s002210000570

Aronoff, R., Matyas, F., Mateo, C., Ciron, C., Schneider, B., \& Petersen, C. C. H. (2010). Longrange connectivity of mouse primary somatosensory barrel cortex. European Journal of Neuroscience, 31(12), 2221-2233. https://doi.org/10.1111/j.1460-9568.2010.07264.x

Avermann, M., Tomm, C., Mateo, C., Gerstner, W., \& Petersen, C. C. H. (2012). Microcircuits of excitatory and inhibitory neurons in layer $2 / 3$ of mouse barrel cortex. Journal of Neurophysiology, 107(11), 3116-3134. https://doi.org/10.1152/jn.00917.2011

Bale, M. R., \& Maravall, M. (2018). Organization of sensory feature selectivity in the whisker system. Neuroscience, 368, 70-80. https://doi.org/10.1016/j.neuroscience.2017.09.014

Bar-llan, L., Gidon, A., \& Segev, I. (2013). The role of dendritic inhibition in shaping the plasticity of excitatory synapses. Frontiers in Neural Circuits, 6(April), 118. https://doi.org/10.3389/fncir.2012.00118

Barthó, P., Freund, T. F., \& Acsády, L. (2002). Selective GABAergic innervation of thalamic nuclei from zona incerta. European Journal of Neuroscience, 16(6), 999-1014. https://doi.org/10.1046/j.1460-9568.2002.02157.x

Beierlein, M., Gibson, J. R., \& Connors, B. W. (2003). Two dynamically distinct inhibitory networks in layer 4 of the neocortex. Journal of Neurophysiology, 90(5), 2987-3000. https://doi.org/10.1152/jn.00283.2003

Berger, T. K., Silberberg, G., Perin, R., \& Markram, H. (2010). Brief bursts self-inhibit and correlate the pyramidal network. PLoS Biology, 8(9). https://doi.org/10.1371/journal.pbio.1000473

Blakemore, C., Clark, J. M., Nevalainen, T., Oberdorfer, M., \& Sussman, A. (2012). Implementing the 3Rs in Neuroscience Research: A Reasoned Approach. Neuron, 75(6), 948-950. https://doi.org/10.1016/j.neuron.2012.09.001

Blatow, M., Rozov, A., Katona, I., Hormuzdi, S. G., Meyer, A. H., Whittington, M. A., ... Monyer, H. (2003). A novel network of multipolar bursting interneurons generates theta frequency oscillations in neocortex. Neuron, 38(5), 805-817. https://doi.org/10.1016/S08966273(03)00300-3

Bokor, H., Frère, S. G. A., Eyre, M. D., Slézia, A., Ulbert, I., Lüthi, A., \& Acsády, L. (2005). Selective GABAergic control of higher-order thalamic relays. Neuron, 45(6), 929-940. https://doi.org/10.1016/j.neuron.2005.01.048

Bortone, D. S., Olsen, S. R., \& Scanziani, M. (2014). Translaminar inhibitory cells recruited by layer 6 corticothalamic neurons suppress visual cortex. Neuron, 82(2), 474-485. https://doi.org/10.1016/j.neuron.2014.02.021

Bosman, L. W. J., Houweling, A. R., Owens, C. B., Tanke, N., Shevchouk, O. T., Rahmati, N., ... De Zeeuw, C. I. (2011). Anatomical Pathways Involved in Generating and Sensing Rhythmic Whisker Movements. Frontiers in Integrative Neuroscience, 5(October), 53. https://doi.org/10.3389/fnint.2011.00053

Bourassa, J., Pinault, D., \& Deschenes, M. (1995). Corticothalamic projections from the cortical barrel field to the somatosensory thalamus in rats: A single-fibre study using biocytin as an anterograde tracer. European Journal of Neuroscience, 7(1), 19-30. https://doi.org/10.1111/j.1460-9568.1995.tb01016.x

Brecht, M., Roth, A., \& Sakmann, B. (2003). Dynamic receptive fields of reconstructed pyramidal cells in layers 3 and 2 of rat somatosensory barrel cortex. Journal of Physiology, 553(1), 243-265. https://doi.org/10.1113/jphysiol.2003.044222

Brecht, M., \& Sakmann, B. (2002a). Dynamic representation of whisker deflection by synaptic potentials in spiny stellate and pyramidal cells in the barrels and septa of layer 4 rat

PeerJ reviewing PDF | (2019:10:42368:1:0:NEW 16 Nov 2020) 
595

596

597

598

599

600

601

602

603

604

605

606

607

608

609

610

611

612

613

614

615

616

617

618

619

620

621

622

623

624

625

626

627

628

629

630

631

632

633

634

635

636

637

638

639

640

641

642

643

644

645

somatosensory cortex. Journal of Physiology, 543(1), 49-70.

https://doi.org/10.1113/jphysiol.2002.018465

Brecht, M., \& Sakmann, B. (2002b). Dynamic representation of whisker deflection by synaptic potentials in spiny stellate and pyramidal cells in the barrels and septa of layer 4 rat somatosensory cortex. The Journal of Physiology, 543(1), 49-70.

https://doi.org/10.1113/jphysiol.2002.018465

Breton, J. D., \& Stuart, G. J. (2012). Somatic and dendritic GABA(B) receptors regulate neuronal excitability via different mechanisms. Journal of Neurophysiology, 108(10), 2810 2818. https://doi.org/10.1152/jn.00524.2012

Bruno, R. M., Hahn, T. T. G., Wallace, D. J., de Kock, C. P. J., \& Sakmann, B. (2009). Sensory experience alters specific branches of individual corticocortical axons during development. The Journal of Neuroscience, 29(10), 3172-3181. https://doi.org/10.1523/JNEUROSCI.5911-08.2009

Bruno, R. M., \& Sakmann, B. (2006). Cortex is driven by weak but synchronously active thalamocortical synapses. Science, 312(5780), 1622-1627. https://doi.org/10.1126/science.1124593

Campagner, D., Evans, M. H., Loft, M. S. E., \& Petersen, R. S. (2018). What the whiskers tell the brain. Neuroscience, 368, 95-108. https://doi.org/10.1016/j.neuroscience.2017.08.005

Caputi, A., Rozov, A., Blatow, M., \& Monyer, H. (2009). Two calretinin-positive gabaergic cell types in layer $2 / 3$ of the mouse neocortex provide different forms of inhibition. Cerebral Cortex, 19(6), 1345-1359. https://doi.org/10.1093/cercor/bhn175

Carron, S. F., Alwis, D. S., \& Rajan, R. (2016). Traumatic Brain Injury and Neuronal Functionality Changes in Sensory Cortex. Frontiers in Systems Neuroscience, 10(June), 47. https://doi.org/10.3389/fnsys.2016.00047

Castro-Alamancos, M. A. (2004). Dynamics of sensory thalamocortical synaptic networks during information processing states. Progress in Neurobiology, 74(4), 213-247. https://doi.org/10.1016/j.pneurobio.2004.09.002

Castro-Alamancos, M. A. (2015). The Whisker Thalamus. In P. Krieger \& A. Groh (Eds.), Sensorimotor Integration in the Whisker System (pp. 31-58). Heidelberg: Springer Science. https://doi.org/10.1007/978-1-4939-2975-7

Castro-Alamancos, M. A., \& Calcagnotto, M. E. (1999). Presynaptic long-term potentiation in corticothalamic synapses. Journal of Neuroscience, 19(20), 9090-9097. https://doi.org/10.1038/361031a0

Castro-Alamancos, M. A. (2002). Properties of primary sensory (lemniscal) synapses in the ventrobasal thalamus and the relay of high-frequency sensory inputs. Journal of Neurophysiology, 87(2), 946-953. https://doi.org/10.1013/jphysiol.2001.013283

Cheetham, C. E. J., Hammond, M. S. L., Edwards, C. E. J., \& Finnerty, G. T. (2007). Sensory experience alters cortical connectivity and synaptic function site specifically. The Journal of Neuroscience, 27(13), 3456-3465. https://doi.org/10.1523/JNEUROSCI.5143-06.2007

Chen, J. L., Carta, S., Soldado-Magraner, J., Schneider, B. L., \& Helmchen, F. (2013). Behaviour-dependent recruitment of long-range projection neurons in somatosensory cortex. Nature, 499(7458), 336-340. https://doi.org/10.1038/nature12236

Chen, J. L., Voigt, F. F., Javadzadeh, M., Krueppel, R., \& Helmchen, F. (2016). Long-range population dynamics of anatomically defined neocortical networks. ELife, 5(MAY2016). https://doi.org/10.7554/eLife.14679

Chittajallu, R., Pelkey, K. a, \& McBain, C. J. (2013). Neurogliaform cells dynamically regulate somatosensory integration via synapse-specific modulation. Nature Neuroscience, 16(1), 13-15. https://doi.org/10.1038/nn.3284

Clancy, B., \& Cauller, L. J. (1999). Widespread projections from subgriseal neurons (layer VII) to layer I in adult rat cortex. Journal of Comparative Neurology, 407(2), 275-286. https://doi.org/10.1002/(SICI)1096-9861(19990503)407:2<275::AID-CNE8>3.0.CO;2-0 
646

647

648

649

650

651

652

653

654

655

656

657

658

659

660

661

662

663

664

665

666

667

668

669

670

671

672

673

674

675

676

677

678

679

680

681

682

683

684

685

686

687

688

689

690

691

692

693

694

695

696

Constantinople, C. M., \& Bruno, R. M. (2013). Deep cortical layers are activated directly by thalamus. Science, 340(6140), 1591-1594. https://doi.org/10.1126/science.1236425

Cowan, A. I., \& Stricker, C. (2004). Functional connectivity in layer IV local excitatory circuits of rat somatosensory cortex. Journal of Neurophysiology, 92(4), 2137-2150. https://doi.org/10.1152/jn.01262.2003

Cruikshank, S. J., Urabe, H., Nurmikko, A. V., \& Connors, B. W. (2010). Pathway-Specific Feedforward Circuits between Thalamus and Neocortex Revealed by Selective Optical Stimulation of Axons. Neuron, 65(2), 230-245. https://doi.org/10.1016/j.neuron.2009.12.025

DeFelipe, J., López-Cruz, P. L., Benavides-Piccione, R., Bielza, C., Larrañaga, P., Anderson, S., ... Ascoli, G. A. (2013). New insights into the classification and nomenclature of cortical GABAergic interneurons. Nature Reviews Neuroscience, 14(3), 202-216. https://doi.org/10.1038/nrn3444

Dehnhardt, G., Hyvärinen, H., Palviainen, A., \& Klauer, G. (1999). Structure and innervation of the vibrissal follicle-sinus complex in the Australian water rat, Hydromys chrysogaster. Journal of Comparative Neurology, 411(4), 550-562. https://doi.org/10.1002/(SICI)10969861(19990906)411:4<550::AID-CNE2>3.0.CO;2-G

Deschênes, M., Veinante, P., \& Zhang, Z. W. (1998). The organization of corticothalamic projections: Reciprocity versus parity. Brain Research Reviews, 28(3), 286-308. https://doi.org/10.1016/S0165-0173(98)00017-4

Diamond, M. E., Armstrong-James, M., \& Ebner, F. F. (1992). Somatic sensory responses in the rostral sector of the posterior group $(\mathrm{POm})$ and in the ventral posterior medial nucleus (VPM) of the rat thalamus. Journal of Comparative Neurology, 318(4), 462-476. https://doi.org/10.1002/cne.903180410

Druckmann, S., Hill, S., Schürmann, F., Markram, H., \& Segev, I. (2013). A hierarchical structure of cortical interneuron electrical diversity revealed by automated statistical analysis. Cerebral Cortex, 23(12), 2994-3006. https://doi.org/10.1093/cercor/bhs290

Ebara, S., Kumamoto, K., Matsuura, T., Mazurkiewicz, J. E., \& Rice, F. L. (2002). Similarities and differences in the innervation of mystacial vibrissal follicle-sinus complexes in the rat and cat: A confocal microscopic study. Journal of Comparative Neurology, 449(2), 103119. https://doi.org/10.1002/cne.10277

Egger, V., Nevian, T., \& Bruno, R. M. (2008). Subcolumnar dendritic and axonal organization of spiny stellate and star pyramid neurons within a barrel in rat somatosensory cortex. Cerebral Cortex, 18(4), 876-889. https://doi.org/10.1093/cercor/bhm126

Feldmeyer, D. (2012). Excitatory neuronal connectivity in the barrel cortex. Frontiers in Neuroanatomy, 6(July), 24. https://doi.org/10.3389/fnana.2012.00024

Feldmeyer, D., Egger, V., Lübke, J., \& Sakmann, B. (1999). Reliable synaptic connections between pairs of excitatory layer 4 neurones within a single 'barrel' of developing rat somatosensory cortex. The Journal of Physiology, 521(1), 169-190. https://doi.org/10.1111/j.1469-7793.1999.00169.x

Feldmeyer, D., Lübke, J., \& Sakmann, B. (2006). Efficacy and connectivity of intracolumnar pairs of layer $2 / 3$ pyramidal cells in the barrel cortex of juvenile rats. The Journal of Physiology, 575(Pt 2), 583-602. https://doi.org/10.1113/jphysiol.2006.105106

Feldmeyer, D., Lübke, J., Silver, R. A., \& Sakmann, B. (2002). Synaptic connections between layer 4 spiny neurone-layer $2 / 3$ pyramidal cell pairs in juvenile rat barrel cortex: physiology and anatomy of interlaminar signalling within a cortical column. The Journal of Physiology, 538(Pt 3), 803-822. https://doi.org/10.1113/jphysiol.2001.012959

Fernandez, L. M. J., Pellegrini, C., Vantomme, G., Béard, E., Lüthi, A., \& Astori, S. (2017). Cortical afferents onto the nucleus Reticularis thalami promote plasticity of low-threshold excitability through GluN2C-NMDARs. Scientific Reports, 7(1). https://doi.org/10.1038/s41598-017-12552-8

Peer] reviewing PDF | (2019:10:42368:1:0:NEW 16 Nov 2020) 
697

698

699

700

701

702

703

704

705

706

707

708

709

710

711

712

713

714

715

716

717

718

719

720

721

722

723

724

725

726

727

728

729

730

731

732

733

734

735

736

737

738

739

740

741

742

743

744

745

746

747

Gentet, L. J. (2012). Functional diversity of supragranular GABAergic neurons in the barrel cortex. Frontiers in Neural Circuits, 6(August), 52. https://doi.org/10.3389/fncir.2012.00052

Gharaei, S., Honnuraiah, S., Arabzadeh, E., \& Stuart, G. J. (2020). Superior colliculus modulates cortical coding of somatosensory information. Nature Communications, 11(1), 1693. https://doi.org/10.1038/s41467-020-15443-1

Golshani, P., Liu, X. B., \& Jones, E. G. (2001). Differences in quantal amplitude reflect GluR4subunit number at corticothalamic synapses on two populations of thalamic neurons. Proceedings of the National Academy of Sciences of the United States of America, 98(7), 4172-4177. https://doi.org/10.1073/pnas.061013698

Halabisky, B. (2006). Electrophysiological Classification of Somatostatin-Positive Interneurons in Mouse Sensorimotor Cortex. Journal of Neurophysiology, 96(2), 834-845. https://doi.org/10.1152/jn.01079.2005

Hartings, J. A., \& Simons, D. J. (1998). Thalamic relay of afferent responses to $1-$ to $12-\mathrm{Hz}$ whisker stimulation in the rat. Journal of Neurophysiology, 80(2), 1016-1019. https://doi.org/10.1152/jn.1998.80.2.1016

Hartmann, M. J., Johnson, N. J., Towal, R. B., \& Assad, C. (2003). Mechanical characteristics of rat vibrissae: Resonant frequencies and damping in isolated whiskers and in the awake behaving animal. Journal of Neuroscience, 23(16), 6510-6519. https://doi.org/10.1523/jneurosci.23-16-06510.2003

Helmstaedter, M., Staiger, J. F., Sakmann, B., \& Feldmeyer, D. (2008). Efficient recruitment of layer $2 / 3$ interneurons by layer 4 input in single columns of rat somatosensory cortex. Journal of Neuroscience, 28(33), 8273-8284. https://doi.org/10.1523/JNEUROSCI.570107.2008

Hevner, R. F., Neogi, T., Englund, C., Daza, R. A. M., \& Fink, A. (2003). Cajal-Retzius cells in the mouse: Transcription factors, neurotransmitters, and birthdays suggest a pallial origin. Developmental Brain Research, 141(1-2), 39-53. https://doi.org/10.1016/S01653806(02)00641-7

Holmgren, C., Harkany, T., \& Zilberter, Y. (2003). Pyramidal cell communication within local networks in layer 2/3 of rat neocortex. Journal of Physiology, 551(1), 139-153. Retrieved from https://www.ncbi.nlm.nih.gov/pubmed/12813147

Hoogland, P. V, Wouterlood, F. G., Welker, E., \& Van der Loos, H. (1991). Ultrastructure of giant and small thalamic terminals of cortical origin: a study of the projections from the barrel cortex in mice using Phaseolus vulgaris leuco-agglutinin (PHA-L). Experimental Brain Research, 87(1), 159-172. https://doi.org/10.1007/BF00228517

Imamoto, K., Karasawa, N., Isomura, G., \& Nagatsu, I. (1994). Cajal-Retzius neurons identified by GABA immunohistochemistry in layer I of the rat cerebral cortex. Neuroscience Research, 20(1), 101-105. https://doi.org/10.1016/0168-0102(94)90027-2

Jensen, K. F., \& Killackey, H. P. (1987). Terminal arbors of axons projecting to the somatosensory cortex of the adult rat. I. The normal morphology of specific thalamocortical afferents. The Journal of Neuroscience, 7(11), 3529-3543. Retrieved from http://www.ncbi.nlm.nih.gov/pubmed/3316526\%5Cnhttp://www.ncbi.nlm.nih.gov/pubmed/3 316525\%5Cnhttp://www.ncbi.nlm.nih.gov/pubmed/3316525

Jia, H., Varga, Z., Sakmann, B., \& Konnerth, A. (2014). Linear integration of spine Ca2+ signals in layer 4 cortical neurons in vivo. Proceedings of the National Academy of Sciences of the United States of America, 111(25), 9277-9282. https://doi.org/10.1073/pnas.1408525111

Jiang, X., Wang, G., Lee, A. J., Stornetta, R. L., \& Zhu, J. J. (2013). The organization of two new cortical interneuronal circuits. Nature Neuroscience, 16(2), 210-218. https://doi.org/10.1038/nn.3305

Johnstone, V. P. A., Shultz, S. R., Yan, E. B., O'Brien, T. J., \& Rajan, R. (2014). The acute phase of mild traumatic brain injury is characterized by a distance-dependent neuronal hypoactivity. Journal of Neurotrauma, 31(22). https://doi.org/10.1089/neu.2014.3343

Peer) reviewing PDF | (2019:10:42368:1:0:NEW 16 Nov 2020) 
748

749

750

751

752

753

754

755

756

757

758

759

760

761

762

763

764

765

766

767

768

769

770

771

772

773

774

775

776

777

778

779

780

781

782

783

784

785

786

787

788

789

790

791

792

793

794

795

796

797

798

Johnstone, V. P. A., Yan, E. B., Alwis, D., \& Rajan, R. (2013). Cortical Hypoexcitation Defines Neuronal Responses in the Immediate Aftermath of Traumatic Brain Injury. PLoS ONE, 8(5). https://doi.org/10.1371/journal.pone.0063454

Jones, E. G. (1975). Varieties and distribution of non-pyramidal cells in the somatic sensory cortex of the squirrel monkey. The Journal of Comparative Neurology, 160(2), 205-267. https://doi.org/10.1002/cne.901600204

Kampa, B. M., Letzkus, J. J., \& Stuart, G. J. (2006). Cortical feed-forward networks for binding different streams of sensory information. Nature Neuroscience, 9(12), 1472-1473. https://doi.org/10.1038/nn1798

Killackey, H. P., \& Sherman, S. M. (2003). Corticothalamic Projections from the Rat Primary Somatosensory Cortex. The Journal of Neuroscience, 23(19), 7381-7384. Retrieved from http://www.jneurosci.org/content/23/19/7381.abstract

Kim, J., Matney, C. J., Blankenship, A., Hestrin, S., \& Brown, S. P. (2014). Layer 6 corticothalamic neurons activate a cortical output layer, layer 5a. Journal of Neuroscience, 34(29), 9656-9664. https://doi.org/10.1523/JNEUROSCl.1325-14.2014

Kim, J. N., Koh, K. S., Lee, E., Park, S. C., \& Song, W. C. (2011). The morphology of the rat vibrissal follicle-sinus complex revealed by three-dimensional computer-aided reconstruction. Cells Tissues Organs, 193(3), 207-214. https://doi.org/10.1159/000319394

Koelbl, C., Helmstaedter, M., L'bke, J., \& Feldmeyer, D. (2015). A barrel-related interneuron in layer 4 of rat somatosensory cortex with a high intrabarrel connectivity. Cerebral Cortex, 25(3), 713-725. https://doi.org/10.1093/cercor/bht263

Kubota, Y., Karube, F., Nomura, M., \& Kawaguchi, Y. (2016). The Diversity of Cortical Inhibitory Synapses. Frontiers in Neural Circuits, 10(April), 1-15. https://doi.org/10.3389/fncir.2016.00027

Kumar, P., \& Ohana, O. (2008). Inter- and intralaminar subcircuits of excitatory and inhibitory neurons in layer 6a of the rat barrel cortex. Journal of Neurophysiology, 100(4), 19091922. https://doi.org/10.1152/jn.90684.2008

Kurotani, T., Yamada, K., Yoshimura, Y., Crair, M. C., \& Komatsu, Y. (2008). State-Dependent Bidirectional Modification of Somatic Inhibition in Neocortical Pyramidal Cells. Neuron, 57(6), 905-916. https://doi.org/10.1016/j.neuron.2008.01.030

Lam, Y. W., \& Sherman, S. M. (2010). Functional organization of the somatosensory cortical layer 6 feedback to the thalamus. Cerebral Cortex, 20(1), 13-24. https://doi.org/10.1093/cercor/bhp077

Land, P. W., Buffer, S. A., \& Yaskosky, J. D. (1995). Barreloids in adult rat thalamus: Threedimensional architecture and relationship to somatosensory cortical barrels. Journal of Comparative Neurology, 355(4), 573-588. https://doi.org/10.1002/cne.903550407

Landisman, C. E., Long, M. A., Beierlein, M., Deans, M. R., Paul, D. L., \& Connors, B. W. (2002). Electrical synapses in the thalamic reticular nucleus. Journal of Neuroscience, 22(3), 1002-1009. https://doi.org/22/3/1002 [pii]

Larkum, M. E. (2013). The yin and yang of cortical layer 1. Nature Neuroscience, 16(2), 114 115. https://doi.org/10.1038/nn.3317

Larsen, DeLaine D., \& Callaway, E. M. (2006). Development of layer-specific axonal arborizations in mouse primary somatosensory cortex. Journal of Comparative Neurology, 494(3), 398-414. https://doi.org/10.1002/cne.20754

Larsen, Delaine D, Wickersham, I. R., \& Callaway, E. M. (2007). Retrograde tracing with recombinant rabies virus reveals correlations between projection targets and dendritic architecture in layer 5 of mouse barrel cortex. Frontiers in Neural Circuits, 1(March), 5. https://doi.org/10.3389/neuro.04.005.2007

Lavallée, P., \& Deschênes, M. (2004). Dendroarchitecture and lateral inhibition in thalamic barreloids. Journal of Neuroscience, 24(27), 6098-6105.

https://doi.org/10.1523/JNEUROSCI.0973-04.2004

Peer) reviewing PDF | (2019:10:42368:1:0:NEW 16 Nov 2020) 
799 Lavallée, P., Urbain, N., Dufresne, C., Bokor, H., Acsády, L., \& Deschênes, M. (2005).

800

801

802

803

804

805

806

807

808

809

810

811

812

813

814

815

816

817

818

819

820

821

822

823

824

825

826

827

828

829

830

831

832

833

834

835

836

837

838

839

840

841

842

843

844

845

846

847

848

849
Feedforward inhibitory control of sensory information in higher-order thalamic nuclei. Journal of Neuroscience, 25(33), 7489-7498. https://doi.org/10.1523/JNEUROSCI.230105.2005

Lavzin, M., Rapoport, S., Polsky, A., Garion, L., \& Schiller, J. (2012). Nonlinear dendritic processing determines angular tuning of barrel cortex neurons in vivo. Nature, 490(7420), 397-401. https://doi.org/10.1038/nature11451

Lazarov, N. E. (2002). Comparative analysis of the chemical neuroanatomy of the mammalian trigeminal ganglion and mesencephalic trigeminal nucleus. Progress in Neurobiology, 66(1), 19-59. https://doi.org/10.1016/S0301-0082(01)00021-1

Le Bé, J. V., Silberberg, G., Wang, Y., \& Markram, H. (2007). Morphological, electrophysiological, and synaptic properties of corticocallosal pyramidal cells in the neonatal rat neocortex. Cerebral Cortex, 17(9), 2204-2213.

https://doi.org/10.1093/cercor/bhl127

Lee, A. J., Wang, G., Jiang, X., Johnson, S. M., Hoang, E. T., Lanté, F., ... Julius Zhu, J. (2014). Canonical Organization of Layer 1 Neuron-Led Cortical Inhibitory and Disinhibitory Interneuronal Circuits. Cerebral Cortex, 2(in mM), 1-13. https://doi.org/10.1093/cercor/bhu020

Lee, S., Kruglikov, I., Huang, Z. J., Fishell, G., \& Rudy, B. (2013). A disinhibitory circuit mediates motor integration in the somatosensory cortex. Nature Neuroscience, 16(11), 1662-1670. https://doi.org/10.1038/nn.3544

Lee, L.-J., \& Erzurumlu, R. S. (2005). Altered parcellation of neocortical somatosensory maps in $\mathrm{N}$-methyl-D-aspartate receptor-deficient mice. The Journal of Comparative Neurology, 485(1), 57-63. https://doi.org/10.1002/cne.20514

Lee, S., Hjerling-Leffler, J., Zagha, E., Fishell, G., \& Rudy, B. (2010). The largest group of superficial neocortical GABAergic interneurons expresses ionotropic serotonin receptors. The Journal of Neuroscience, 30(50), 16796-16808. https://doi.org/10.1523/JNEUROSCI.1869-10.2010

Lefort, S., Tomm, C., Sarria, J. C. F., \& Petersen, C. C. H. (2009). The Excitatory Neuronal Network of the C2 Barrel Column in Mouse Primary Somatosensory Cortex. Neuron, 61(2), 301-316. https://doi.org/10.1016/j.neuron.2008.12.020

Lichtenstein, S. H., Carvell, G. E., \& Simons, D. J. (1990). Responses of rat trigeminal ganglion neurons to movements of vibrissae in different directions. Somatosensory \& Motor Research, 7(1), 47-65. https://doi.org/10.3109/08990229009144697

Lübke, J., Egger, V., Sakmann, B., \& Feldmeyer, D. (2000). Columnar organization of dendrites and axons of single and synaptically coupled excitatory spiny neurons in layer 4 of the rat barrel cortex. The Journal of Neuroscience, 20(14), 5300-5311. https://doi.org/20/14/5300 [pii]

Lucas, L., Katiri, R., \& Kitterick, P. T. (2018). The psychological and social consequences of single-sided deafness in adulthood. International Journal of Audiology, 57(1), 21-30. https://doi.org/10.1080/14992027.2017.1398420

Lyall, E. H., Mossing, D. P., Pluta, S. R., Dudai, A., \& Adesnik, H. (2020). Synthesis of higher order feature codes through stimulus-specific supra-linear summation. BioRxiv, 1-42. https://doi.org/https://doi.org/10.1101/2020.06.24.169359

Ma, Y., Hu, H., Berrebi, A. S., Mathers, P. H., \& Agmon, A. (2006). Distinct subtypes of somatostatin-containing neocortical interneurons revealed in transgenic mice. The Journal of Neuroscience, 26(19), 5069-5082. https://doi.org/10.1523/JNEUROSCI.0661-06.2006

Maravall, M., Petersen, R. S., Fairhall, A. L., Arabzadeh, E., \& Diamond, M. E. (2007). Shifts in coding properties and maintenance of information transmission during adaptation in barrel cortex. PLoS Biology, 5(2), 0323-0334. https://doi.org/10.1371/journal.pbio.0050019

Markram, H., Toledo-Rodriguez, M., Wang, Y., Gupta, A., Silberberg, G., \& Wu, C. (2004). 
850

851

852

853

854

855

856

857

858

859

860

861

862

863

864

865

866

867

868

869

870

871

872

873

874

875

876

877

878

879

880

881

882

883

884

885

886

887

888

889

890

891

892

893

894

895

896

897

898

899

900

Interneurons of the neocortical inhibitory system. Nature Reviews Neuroscience, 5(10), 793-807. https://doi.org/10.1038/nrn1519

Marshall, C. D., Amin, H., Kovacs, K. M., \& Lydersen, C. (2006). Microstructure and innervation of the mystacial vibrissal follicle-sinus complex in bearded seals, Erignathus barbatus (Pinnipedia: Phocidae). Anatomical Record: Part A, Discoveries in Molecular, Cellular, and Evolutionary Biology, 288(1), 13-25. https://doi.org/10.1002/ar.a.20273

Marx, M., \& Feldmeyer, D. (2013). Morphology and physiology of excitatory neurons in layer $6 \mathrm{~b}$ of the somatosensory rat barrel cortex. Cerebral Cortex, 23(12), 2803-2817. https://doi.org/10.1093/cercor/bhs254

McCormick, D. A., \& von Krosigk, M. (1992). Corticothalamic activation modulates thalamic firing through glutamate "metabotropic" receptors. Proceedings of the National Academy of Sciences of the United States of America, 89(7), 2774-2778. https://doi.org/10.1073/pnas.89.7.2774

Melaragna, H. P., \& Montagna, W. (1953). The tactile hair follicles in the mouse. The Anatomical Record, 115(2), 129-149. https://doi.org/10.1002/ar.1091150202

Mercer, A., West, D. C., Morris, O. T., Kirchhecker, S., Kerkhoff, J. E., \& Thomson, A. M. (2005). Excitatory connections made by presynaptic cortico-cortical pyramidal cells in layer 6 of the neocortex. Cerebral Cortex, 15(10), 1485-1496. https://doi.org/10.1093/cercor/bhi027

Meyer, H. S., Schwarz, D., Wimmer, V. C., Schmitt, a. C., Kerr, J. N. D., Sakmann, B., \& Helmstaedter, M. (2011). Inhibitory interneurons in a cortical column form hot zones of inhibition in layers 2 and 5A. Proceedings of the National Academy of Sciences of the United States of America, 108(40), 16807-16812. https://doi.org/10.1073/pnas.1113648108

Meyer, Hanno S., Wimmer, V. C., Hemberger, M., Bruno, R. M., De Kock, C. P. J., Frick, A., ... Helmstaedter, M. (2010). Cell type-specific thalamic innervation in a column of rat vibrissal cortex. Cerebral Cortex, 20(10), 2287-2303. https://doi.org/10.1093/cercor/bhq069

Minamisawa, G., Kwon, S. E., Chevée, M., Brown, S. P., \& O’Connor, D. H. (2018). A Noncanonical Feedback Circuit for Rapid Interactions between Somatosensory Cortices. Cell Reports, 23(9), 2718-2731.e6. https://doi.org/10.1016/j.celrep.2018.04.115

Miyata, M., \& Imoto, K. (2006). Different composition of glutamate receptors in corticothalamic and lemniscal synaptic responses and their roles in the firing responses of ventrobasal thalamic neurons in juvenile mice. Journal of Neurophysiology, 575(Pt 1), 161-174. https://doi.org/10.1113/jphysiol.2006.114413

Morton, D. (2013). The Trigeminal System. In A. Iggo (Ed.), Handbook of Sensory Physiology, Somatosensory Systems (pp. 271-314). Berlin: Springer-Verlag. Retrieved from http://library.med.utah.edu/diganat/SOM/dental.neuro/05 Trigeminal system 2013.pdf

Neimark, M. A., Andermann, M. L., Hopfield, J. J., \& Moore, C. I. (2003). Vibrissa resonance as a transduction mechanism for tactile encoding. Journal of Neuroscience, 23(16), 64996509. https://doi.org/10.1523/jneurosci.23-16-06499.2003

O'Herron, P., Levy, M., Woodward, J. J., \& Kara, P. (2020). An unexpected dependence of cortical depth in shaping neural responsiveness and selectivity in mouse visual cortex. ENeuro, 7(2). https://doi.org/10.1523/ENEURO.0497-19.2020

Oberlaender, M., Boudewijns, Z. S. R. M., Kleele, T., Mansvelder, H. D., Sakmann, B., \& de Kock, C. P. J. (2011). Three-dimensional axon morphologies of individual layer 5 neurons indicate cell type-specific intracortical pathways for whisker motion and touch. Proceedings of the National Academy of Sciences of the United States of America, 108(10), 4188-4193. https://doi.org/10.1073/pnas.1100647108

Oberlaender, Marcel, De Kock, C. P. J., Bruno, R. M., Ramirez, A., Meyer, H. S., Dercksen, V. J., ... Sakmann, B. (2012). Cell type-specific three-dimensional structure of thalamocortical circuits in a column of rat vibrissal cortex. Cerebral Cortex, 22(10), 2375-2391. 
901

902

903

904

905

906

907

908

909

910

911

912

913

914

915

916

917

918

919

920

921

922

923

924

925

926

927

928

929

930

931

932

933

934

935

936

937

938

939

940

941

942

943

944

945

946

947

948

949

950

951

https://doi.org/10.1093/cercor/bhr317

Ohno, S., Kuramoto, E., Furuta, T., Hioki, H., Tanaka, Y. R., Fujiyama, F., ... Kaneko, T. (2012). A morphological analysis of thalamocortical axon fibers of rat posterior thalamic nuclei: $A$ single neuron tracing study with viral vectors. Cerebral Cortex, 22(12), 2840-2857. https://doi.org/10.1093/cercor/bhr356

Panzeri, S., Petroni, F., Petersen, R. S., \& Diamond, M. E. (2003). Decoding neuronal population activity in rat somatosensory cortex: Role of columnar organization, 13(1), 4552.

Perrenoud, Q., Rossier, J., Geoffroy, H., Vitalis, T., \& Gallopin, T. (2013). Diversity of gabaergic interneurons in layer Vla and VIb of mouse barrel cortex. Cerebral Cortex, 23(2), 423-441. https://doi.org/10.1093/cercor/bhs032

Petersen, R. S., Panzeri, S., \& Diamond, M. E. (2001). Population coding of stimulus location in rat somatosensory cortex. Neuron, 32(3), 503-514. https://doi.org/10.1016/S08966273(01)00481-0

Petreanu, L., Mao, T., Sternson, S. M., \& Svoboda, K. (2009). The subcellular organization of neocortical excitatory connections. Nature, 457(7233), 1142-1145. https://doi.org/10.1038/nature07709

Phoka, E., Wildie, M., Schultz, S. R., \& Barahona, M. (2012). Sensory experience modifies spontaneous state dynamics in a large-scale barrel cortical model. Journal of Computational Neuroscience, 33(2), 323-339. https://doi.org/10.1007/s10827-012-0388-6

Pichon, F., Nikonenko, I., Kraftsik, R., \& Welker, E. (2012). Intracortical connectivity of layer VI pyramidal neurons in the somatosensory cortex of normal and barrelless mice. European Journal of Neuroscience, 35(6), 855-869. https://doi.org/10.1111/j.14609568.2012.08011.x

Pierret, T., Lavallee, P., \& Deschenes, M. (2000). Parallel streams for the relay of vibrissal information through thalamic barreloids. Journal of Neuroscience, 20(19), 7455-7462. https://doi.org/10.1523/jneurosci.20-19-07455.2000

Pierret, T., Lavallée, P., \& Deschênes, M. (2000). Parallel streams for the relay of vibrissal information through thalamic barreloids. Journal of Neuroscience, 20(19), 7455-7462.

Pinto, D. J., Brumberg, J. C., \& Simons, D. J. (2000). Circuit dynamics and coding strategies in rodent somatosensory cortex. Journal of Neurophysiology, 83(3), 1158-1166. https://doi.org/10.1152/jn.2000.83.3.1158

Porter, J. T., Johnson, C. K., \& Agmon, A. (2001). Diverse types of interneurons generate thalamus-evoked feedforward inhibition in the mouse barrel cortex. Journal of Neuroscience, 21(8), 2699-2710. https://doi.org/21/8/2699 [pii]

Radnikow, G., Qi, G., \& Feldmeyer, D. (2015). Synaptic Microcircuits in the Barrel Cortex. In P. Krieger \& A. Groh (Eds.), Sensorimotor Integration in the Whisker System (pp. 59-108). Heidelberg: Springer Science. https://doi.org/10.1007/978-1-4939-2975-7

Reichova, I. (2004). Somatosensory Corticothalamic Projections: Distinguishing Drivers From Modulators. Journal of Neurophysiology, 92(4), 2185-2197. https://doi.org/10.1152/jn.00322.2004

Reid, R. C., \& Koch, C. (2012). Observatories of the mind. Nature, 483(7390), 397-398. https://doi.org/10.1038/483397a

Reyes, A., \& Sakmann, B. (1999). Developmental switch in the short-term modification of unitary EPSPs evoked in layer $2 / 3$ and layer 5 pyramidal neurons of rat neocortex. The Journal of Neuroscience, 19(10), 3827-3835.

Rice, F. L., Mance, A., \& Munger, B. L. (1986). A comparative light microscopic analysis of the sensory innervation of the mystacial pad. I. Innervation of vibrissal follicle-sinus complexes. Journal of Comparative Neurology, 252(2), 154-174. https://doi.org/10.1002/cne.902520203

Rubio-Garrido, P., Pérez-De-Manzo, F., Porrero, C., Galazo, M. J., \& Clascá, F. (2009).

Peer] reviewing PDF | (2019:10:42368:1:0:NEW 16 Nov 2020) 
952

953

954

955

956

957

958

959

960

961

962

963

964

965

966

967

968

969

970

971

972

973

974

975

976

977

978

979

980

981

982

983

984

985

986

987

988

989

990

991

992

993

994

995

996

997

998

999

1000

1001

1002
Thalamic input to distal apical dendrites in neocortical layer 1 is massive and highly convergent. Cerebral Cortex, 19(10), 2380-2395. https://doi.org/10.1093/cercor/bhn259

Rudy, B., Fishell, G., Lee, S., \& Hjerling-Leffler, J. (2011). Three groups of interneurons account for nearly $100 \%$ of neocortical GABAergic neurons. Developmental Neurobiology, 71(1), 45-61. https://doi.org/10.1002/dneu.20853

Saporta, S., \& Kruger, L. (1977). The organization of thalamocortical relay neurons in the rat ventrobasal complex studied by the retrograde transport of horseradish peroxidase. Journal of Comparative Neurology, 174(2), 187-208. https://doi.org/10.1002/cne.901740202

Sarid, L., Feldmeyer, D., Gidon, A., Sakmann, B., \& Segev, I. (2015). Contribution of intracolumnar layer 2/3-to-Layer $2 / 3$ excitatory connections in shaping the response to whisker deflection in rat barrel cortex. Cerebral Cortex, 25(4), 849-858. https://doi.org/10.1093/cercor/bht268

Schoonover, C. E., Tapia, J.-C., Schilling, V. C., Wimmer, V., Blazeski, R., Zhang, W., ... Bruno, R. M. (2014). Comparative strength and dendritic organization of thalamocortical and corticocortical synapses onto excitatory layer 4 neurons. Journal of Neuroscience, 34(20), 6746-6758. https://doi.org/10.1523/JNEUROSCI.0305-14.2014

Schubert, D., Kötter, R., Luhmann, H. J., \& Staiger, J. F. (2006). Morphology, electrophysiology and functional input connectivity of pyramidal neurons characterizes a genuine layer $\mathrm{Va}$ in the primary somatosensory cortex. Cerebral Cortex, 16(2), 223-236. https://doi.org/10.1093/cercor/bhi100

Schubert, Dirk, Kotter, R., Zilles, K., Luhmann, H. J., \& Staiger, J. F. (2003). Cell Type-Specific Circuits of Cortical Layer IV Spiny Neurons. Journal of Neuroscience, 23(7), 2961-2970. Retrieved from http://www.jneurosci.org/content/23/7/2961

Semple, B. D., Blomgren, K., Gimlin, K., Ferriero, D. M., \& Noble-Haeusslein, L. J. (2012). Brain development in rodents and humans: Identifying benchmarks of maturation and vulnerability to injury across species. Progress in Neurobiology, 100(2), 130-134. https://doi.org/10.1016/j.pestbp.2011.02.012.Investigations

Sherman, S. M., \& Guillery, R. W. (1998). On the actions that one nerve cell can have on another: distinguishing "drivers" from "modulators". Proceedings of the National Academy of Sciences of the United States of America, 95(12), 7121-7126. https://doi.org/10.1073/pnas.95.12.7121

Shoykhet, M., Doherty, D., \& Simons, D. J. (2000). Coding of deflection velocity and amplitude by whisker primary afferent neurons: Implications for higher level processing. Somatosensory and Motor Research, 17(2), 171-180. https://doi.org/10.1080/08990220050020580

Silberberg, G., \& Markram, H. (2007). Disynaptic Inhibition between Neocortical Pyramidal Cells Mediated by Martinotti Cells. Neuron, 53(5), 735-746. https://doi.org/10.1016/j.neuron.2007.02.012

Sohal, V. S., \& Huguenard, J. R. (2003). Inhibitory interconnections control burst pattern and emergent network synchrony in reticular thalamus. Journal of Neuroscience, 23(26), 89788988. https://doi.org/23/26/8978 [pii]

Staiger, J. F., Bojak, I., Miceli, S., \& Schubert, D. (2014). A gradual depth-dependent change in connectivity features of supragranular pyramidal cells in rat barrel cortex. Brain Structure and Function, 1-21. https://doi.org/10.1007/s00429-014-0726-8

Staiger, J. F., Flagmeyer, I., Schubert, D., Zilles, K., Kötter, R., \& Luhmann, H. J. (2004). Functional diversity of layer IV spiny neurons in rat somatosensory cortex: Quantitative morphology of electrophysiologically characterized and biocytin labeled cells. Cerebral Cortex, 14(6), 690-701. https://doi.org/10.1093/cercor/bhh029

Steriade, M., Jones, E., \& McCormick, D. (1997). Thalamus. Oxford: Elsevier. Stuart, G. J. (2012). Dendritic Spikes Veto Inhibition. Neuron, 75(5), 744-746. 
1003

1004

1005

1006

1007

1008

1009

1010

1011

1012

1013

1014

1015

1016

1017

1018

1019

1020

1021

1022

1023

1024

1025

1026

1027

1028

1029

1030

1031

1032

1033

1034

1035

1036

1037

1038

1039

1040

1041

1042

1043

1044

1045

1046

1047

1048

1049

1050

1051

1052

1053

https://doi.org/10.1016/j.neuron.2012.08.024

Stuttgen, M. C., Ruter, J., \& Schwarz., C. (2006). Two psychophysical channels of whisker deflection in rats align with two neuronal classes of primary afferents. Journal of Neuroscience, 26(30)(30), 7933-7941. https://doi.org/10.1523/JNEUROSCI.1864-06.2006

Szabadics, J., Varga, C., Molnár, G., Oláh, S., Barzó, P., \& Tamás, G. (2006). Excitatory effect of GABAergic axo-axonic cells in cortical microcircuits. Science, 311(5758), 233-235. https://doi.org/10.1126/science.1121325

Tan, Z., Hu, H., Huang, Z. J., \& Agmon, A. (2008). Robust but delayed thalamocortical activation of dendritic-targeting inhibitory interneurons. Proceedings of the National Academy of Sciences of the United States of America, 105(6), 2187-2192. https://doi.org/10.1073/pnas.0710628105

Temereanca, S., \& Simons, D. J. (2003). Local field potentials and the encoding of whisker deflections by population firing synchrony in thalamic barreloids. Journal of Neurophysiology, 89(4), 2137-2145. https://doi.org/10.1152/jn.00582.2002

Thomson, A. M. (2010). Neocortical layer 6, a review. Frontiers in Neuroanatomy, 4(March), 13. https://doi.org/10.3389/fnana.2010.00013

Trageser, J. C., \& Keller, A. (2004). Reducing the Uncertainty: Gating of Peripheral Inputs by Zona Incerta. Journal of Neuroscience, 24(40), 8911-8915. https://doi.org/10.1523/JNEUROSCI.3218-04.2004

Varga, C., Sík, A., Lavallée, P., \& Deschênes, M. (2002). Dendroarchitecture of relay cells in thalamic barreloids: a substrate for cross-whisker modulation. Journal of Neuroscience, 22(14), 6186-6194. https://doi.org/20026602

Veinante, P., Lavallée, P., \& Deschênes, M. (2000). Corticothalamic projections from layer 5 of the vibrissal barrel cortex in the rat. Journal of Comparative Neurology, 424(2), 197-204. https://doi.org/10.1002/1096-9861(20000821)424:2<197::AID-CNE1>3.0.CO;2-6

West, D. C., Mercer, A., Kirchhecker, S., Morris, O. T., \& Thomson, A. M. (2006). Layer 6 cortico-thalamic pyramidal cells preferentially innervate interneurons and generate facilitating EPSPs. Cerebral Cortex, 16(2), 200-211. https://doi.org/10.1093/cercor/bhi098

White, E. L., \& Rock, M. P. (1979). Distribution of thalamic input to different dendrites of a spiny stellate cell in mouse sensorimotor cortex. Neuroscience Letters, 15(2-3), 115-119. https://doi.org/10.1016/0304-3940(79)96099-3

White, E. L., \& Rock, M. P. (1981). A comparison of thalamocortical and other synaptic inputs to dendrites of two non-spiny neurons in a single barrel of mouse Sml cortex. Journal of Comparative Neurology, 195(2), 265-277. https://doi.org/10.1002/cne.901950207

WHO Programme for the Prevention of Deafness and Hearing Impairment. (2001). Report of the informal consultation on the economic analysis of sensory disabilities, WHO, Geneva 28-29 November 2000. Retrieved from http://whqlibdoc.who.int/hq/2001/WHO_PBD_01.1.pdf

WHO Programme for the Prevention of Deafness and Hearing Impairment. (2010). Global Data on Visual Impairments 2010. Retrieved from http://www.who.int/topics/blindness/en/

Wood-Jackson, C., \& Turnbull, A. (2004). Impact of Deafness on Family Life: A Review of the Literature. Topics in Early Childhood Special Education, 24(1), 15-29. https://doi.org/10.1177/02711214040240010201

Wozny, C., \& Williams, S. R. (2011). Specificity of synaptic connectivity between layer 1 inhibitory interneurons and layer $2 / 3$ pyramidal neurons in the rat neocortex. Cerebral Cortex, 21(8), 1818-1826. https://doi.org/10.1093/cercor/bhq257

Xu, H., Jeong, H.-Y., Tremblay, R., \& Rudy, B. (2013). Neocortical somatostatin-expressing GABAergic interneurons disihibit the thalamorecipient layer 4. Neuron, 77(1), 155-167. https://doi.org/10.1016/j.neuron.2012.11.004

Xu, N., Harnett, M. T., Williams, S. R., Huber, D., O'Connor, D. H., Svoboda, K., \& Magee, J. C. (2012). Nonlinear dendritic integration of sensory and motor input during an active sensing task. Nature, 492(7428), 247-251. https://doi.org/10.1038/nature11601

PeerJ reviewing PDF | (2019:10:42368:1:0:NEW 16 Nov 2020) 
1054 Yohro, T. (1977). Structure of the sinus hair follicle in the big-clawed shrew, Sorex unguiculatus. Journal of Morphology, 153(2), 333-353. https://doi.org/10.1002/jmor.1051530211 whisking and touch signals in the rat. PLoS Biology, 4(5), 819-825. https://doi.org/10.1371/journal.pbio.0040124

Zhang, Z. W., \& Deschênes, M. (1997). Intracortical axonal projections of lamina VI cells of the primary somatosensory cortex in the rat: a single-cell labeling study. The Journal of Neuroscience, 17(16), 6365-6379.

Zucker, E., \& Welker, W. I. (1969). Coding of somatic sensory input by vibrissae neurons in the rat's trigeminal ganglion. Brain Research, 12(1), 138-156. https://doi.org/10.1016/0006-

1065 8993(69)90061-4 


\section{Figure 1}

Simplified diagrammatic overview of known pathways of input to and interactions with a single barrel column

Still finer details exist within these structures but are not shown, e.g. barrelletes (found within the brain stem and a sub-area of PrV). Intra-barrel column microcircuits also play an important dynamical role in modulating these pathways and is discussed in the text. Arrowheads indicate direction of projection, "+" symbol indicates relatively strong connections, and lighter colours indicate relatively weak connections. (Key: green=excitatory, red=inhibitory, purple=modulatory. Abbreviations same as text.) 


\section{Barrel cortex}

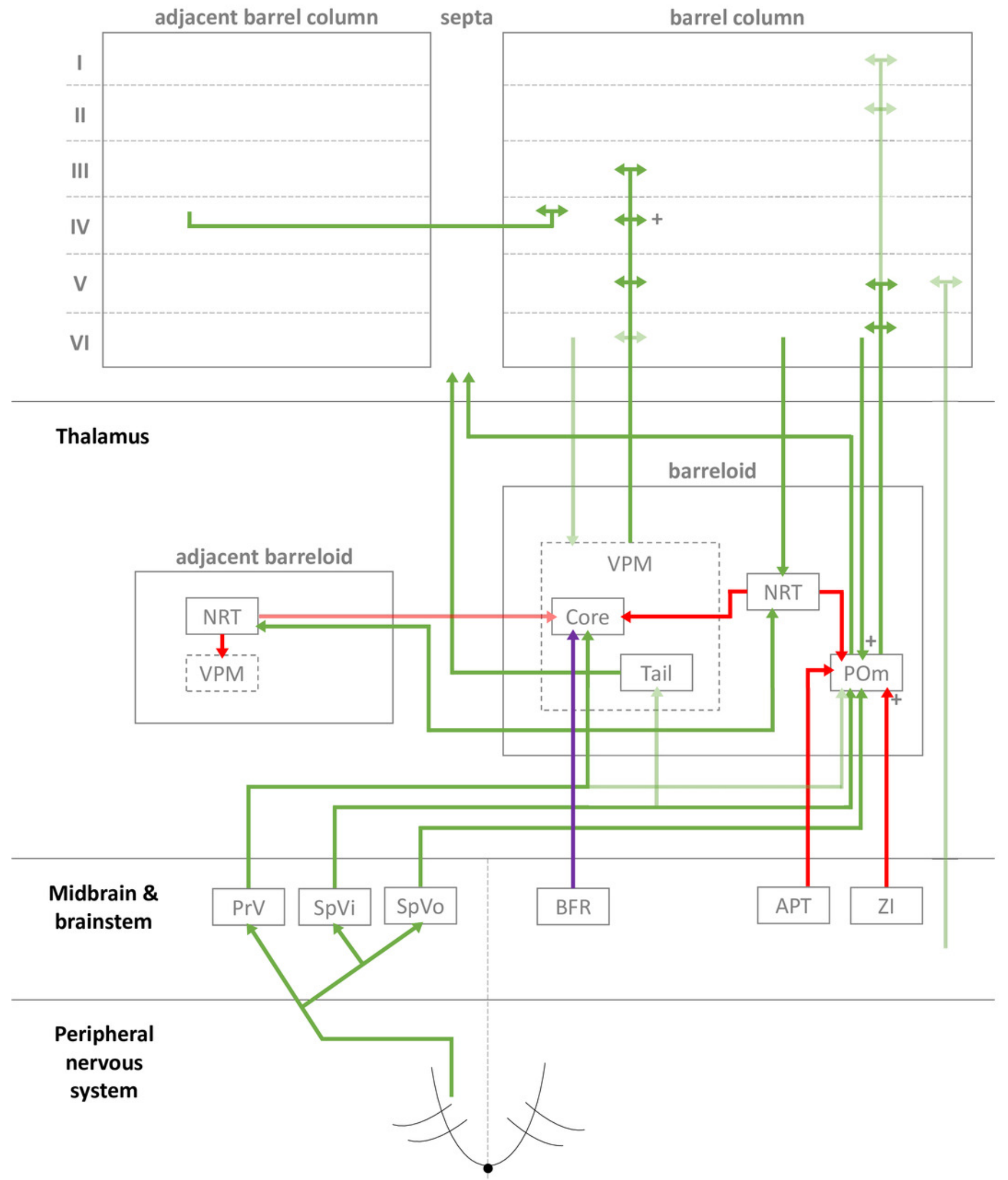

right hemisphere

left hemisphere 


\section{Table 1 (on next page)}

Summary of interneuron sub-types mentioned in text (abbreviations same as text). 


\begin{tabular}{|c|c|c|}
\hline Name & Basic description & $\begin{array}{l}\text { Identifying characteristics (Druckmann } \\
\text { et al., 2013; Markram et al., 2015, } \\
\text { 2004; Radnikow et al., 2015) }\end{array}$ \\
\hline $\begin{array}{l}\text { Spiny stellate } \\
\text { cell (SSC) }\end{array}$ & $\begin{array}{l}\text { Filters and relays thalamic excitation } \\
\text { from layer IV to layer II/III (Dirk } \\
\text { Schubert et al., 2003). }\end{array}$ & Spiny morphology. \\
\hline $\begin{array}{l}\text { Large basket } \\
\text { cell (LBC) }\end{array}$ & $\begin{array}{l}\text { Most common basket cell found in } \\
\text { cortex (Markram et al., 2004). } \\
\text { Inhibits many pyramidal cells across } \\
\text { barrels at or near the soma (Wang, } \\
2002 \text { ). }\end{array}$ & $\begin{array}{l}\text { FS, non-accommodating (N-Ac), non- } \\
\text { adapting (N-Ad). } \\
\text { PV }(+++), \text { CB }(++), \operatorname{NPY}(+), \text { CR }(+) \\
\operatorname{VIP}(+), \operatorname{SOM}(-), \operatorname{CCK}(+)\end{array}$ \\
\hline $\begin{array}{l}\text { Small basket } \\
\text { cell (SBC) }\end{array}$ & $\begin{array}{l}\text { Least common basket cell found in } \\
\text { cortex (Markram et al., 2004). } \\
\text { Inhibits few pyramidal cells, usually } \\
\text { within a single layer and column, at } \\
\text { or near the soma (Wang, 2002). }\end{array}$ & $\begin{array}{l}\text { FS, N-Ac, N-Ad. } \\
\text { PV (-), CB }(++), \operatorname{NPY}(+), \text { CR }(-), \text { VIP } \\
(+++), \operatorname{SOM}(++), \operatorname{CCK}(+)\end{array}$ \\
\hline $\begin{array}{l}\text { Nest basket } \\
\text { cell (NBC) }\end{array}$ & $\begin{array}{l}\text { Second-most common basket cell } \\
\text { found in cortex (Markram et al., } \\
\text { 2004). Inhibits few pyramidal cells } \\
\text { within a barrel at or near the soma } \\
\text { (Wang, 2002). }\end{array}$ & $\begin{array}{l}\text { FS, N-Ac, N-Ad. } \\
\text { PV }(+++), \text { CB }(++), \operatorname{NPY}(+), \text { CR }(++) \\
\operatorname{VIP}(+), \operatorname{SOM}(-), \operatorname{CCK}(+)\end{array}$ \\
\hline $\begin{array}{l}\text { Chandelier } \\
\text { cell (ChC) }\end{array}$ & $\begin{array}{l}\text { Inhibits the initial segment of } \\
\text { pyramidal neurons and found in } \\
\text { layers II to VI (Borden, 1996; } \\
\text { Hardwick et al., 2005; Markram et } \\
\text { al., 2004; Taniguchi et al., 2013; } \\
\text { Woodruff and Yuste, 2008) to } \\
\text { control excessive excitation (Zhu et } \\
\text { al., 2004), although some } \\
\text { connections could themselves be } \\
\text { excitatory (Szabadics et al., 2006). }\end{array}$ & $\begin{array}{l}\text { FS or late spiking (LS), N-Ad. } \\
\text { PV }(+) \text { and/or CB }(+), \text { GABA } \\
\text { transporter } 1(\text { GAT-1) }(+) \text {, SOM (-). }\end{array}$ \\
\hline Neurogliaform & Inhibits dendrites of pyramidal & LS. \\
\hline
\end{tabular}




\begin{tabular}{|c|c|c|}
\hline cell (NGFC) & $\begin{array}{l}\text { neurons (Markram et al., 2004), } \\
\text { especially in instances of persistent } \\
\text { excitation (Overstreet-Wadiche and } \\
\text { McBain, 2015; Norimitsu Suzuki et } \\
\text { al., 2014). }\end{array}$ & $\begin{array}{l}\text { PV (-), CB }(-), \text { NPY }(+) \text {, reelin }(+), \\
\text { COUP transcription factor } 2(+) .\end{array}$ \\
\hline $\begin{array}{l}\text { Double } \\
\text { bouquet cell } \\
\text { (DBoC) }\end{array}$ & $\begin{array}{l}\text { Inhibits basal dendrites and somas } \\
\text { of pyramidal neurons (Markram et } \\
\text { al., 2004), typically extending its } \\
\text { dendrites vertically, across multiple } \\
\text { layers (Kawaguchi and Kubota, } \\
\text { 1996; Krimer, 2005; Somogyi, P; } \\
\text { Cowey, 1984). }\end{array}$ & $\begin{array}{l}\text { Irregular spiking (IS) or regular non- } \\
\text { pyramidal (RSNP) firing (adapting). } \\
\text { PV (-), CB (-), NPY (-), CR (++), VIP } \\
(+++), \text { SOM (++). }\end{array}$ \\
\hline $\begin{array}{l}\text { Bitufted cell } \\
\text { (BTC) }\end{array}$ & $\begin{array}{l}\text { Inhibits distal dendrites of pyramidal } \\
\text { neurons (Markram et al., 2004), } \\
\text { often spanning its dendrites across } \\
\text { the entire cortical column (Kaiser et } \\
\text { al., 2001; Peters and Harriman, } \\
\text { 1988; Tamás et al., 1998). }\end{array}$ & $\begin{array}{l}\text { RSNP and BSNP, adapting. } \\
\text { PV (-), CB (++), NPY }(+), \text { CR }(++), \\
\text { VIP }(+), \text { SOM }(++) \\
\text {. }\end{array}$ \\
\hline $\begin{array}{l}\text { Bipolar cell } \\
\text { (BPC) }\end{array}$ & $\begin{array}{l}\text { Extends narrow bipolar or bitufted } \\
\text { dendrites vertically within the } \\
\text { column. Inhibits the basal dendrites } \\
\text { of relatively few pyramidal neurons } \\
\text { (Markram et al., 2004). }\end{array}$ & $\begin{array}{l}\text { IS, LS, or RSNP (adapting). } \\
\text { PV (-), CB (-), NPY (-), CR (++), VIP } \\
(+++), \text { SOM }(++) .\end{array}$ \\
\hline $\begin{array}{l}\text { Multipolar } \\
\text { bursting cell } \\
\text { (MPBC) }\end{array}$ & $\begin{array}{l}\text { Extends densely within layer II, with } \\
\text { some collaterals to layer V. Inhibits } \\
\text { the basal dendrites of local } \\
\text { pyramidal neurons (Blatow et al., } \\
\text { 2003; Caputi et al., 2009). }\end{array}$ & $\begin{array}{l}\text { Burst firing. } \\
\mathrm{CR}(+)\end{array}$ \\
\hline $\begin{array}{l}\text { Martinotti cell } \\
(\mathrm{MC})\end{array}$ & $\begin{array}{l}\text { Inhibit distal dendrites of pyramidal } \\
\text { neurons (Markram et al., 2004), } \\
\text { especially the apical tuft regions in } \\
\text { layer I (of deeper pyramidal } \\
\text { neurons). }\end{array}$ & $\begin{array}{l}\text { RSNP or burst-spiking non-pyramidal } \\
\text { (BSNP). } \\
\text { PV (-), CB }(++) \text {, NPY }(++), \text { CR }(-) \text {, VIP } \\
(-) \text {, SOM }(+++) .\end{array}$ \\
\hline
\end{tabular}




\begin{tabular}{|l|l|l|}
\hline $\begin{array}{l}\text { Single } \\
\text { bouquet cell } \\
\text { (SBoC) }\end{array}$ & $\begin{array}{l}\text { Inhibits interneurons in } \\
\text { supragranular layers, indirectly } \\
\text { disinhibiting layer V pyramidal } \\
\text { neurons (Jiang et al., 2013; Larkum, } \\
\text { 2013; Alice J. Lee et al., 2014). }\end{array}$ & Typically VIP (+). \\
\hline $\begin{array}{l}\text { Elongated } \\
\text { neurogliaform (ENGFC) }\end{array}$ & $\begin{array}{l}\text { Inhibits distal dendrites present in } \\
\text { layer I, typically the apical tufts, of } \\
\text { layer II, III, and V pyramidal neurons } \\
\text { (Jiang et al., 2013; Larkum, 2013; } \\
\text { Alice J. Lee et al., 2014). }\end{array}$ & $\begin{array}{l}\text { LS and varied spiking patterns. } \\
\text { Typically NPY (+) and reelin (+). }\end{array}$ \\
\hline cell & $\begin{array}{l}\text { Important for establishing } \\
\text { intracortical and cortico-thalamic } \\
\text { connections during development } \\
\text { (Del Río et al., 1997; Hevner et al., } \\
\text { 2003; Imamoto et al., 1994; G. } \\
\text { Meyer et al., 1999; Soriano and Del } \\
\text { Río, 2005), although some may } \\
\text { survive into adulthood (G. Meyer et } \\
\text { al., 1999; Soriano and Del Río, } \\
\text { 2005). }\end{array}$ & Typically reelin (+). \\
\hline
\end{tabular}

